\title{
IGF-binding protein-4: biochemical characteristics and functional consequences
}

\author{
R Zhou, ${ }^{1,2}$, D Diehl ${ }^{1}$, A Hoeflich ${ }^{1}$, H Lahm $^{3}$ and E Wolf ${ }^{1}$ \\ ${ }^{1}$ Institute of Molecular Animal Breeding and Biotechnology, Gene Center of the University of Munich, 81377 Munich, Germany \\ ${ }^{2}$ College of Animal Science and Veterinary Medicine, Huazhong Agricultural University, 430070 Wuhan, China \\ ${ }^{3}$ Immunology-Molecular Biology Laboratory, Thoraxklinik Heidelberg gGmbH, 69126 Heidelberg, Germany \\ (Requests for offprints should be addressed to R Zhou; Email: zhou@Imb.uni-muenchen.de)
}

\begin{abstract}
IGFs have multiple functions regarding cellular growth, survival and differentiation under different physiological and pathological conditions. IGF effects are modulated systemically and locally by six high-affinity IGF-binding proteins (IGFBP-1 to -6). Despite their structural similarity, each IGFBP has unique properties and exhibits specific functions. IGFBP-4, the smallest IGFBP, exists in both non-glycosylated and $\mathrm{N}$-glycosylated forms in all biological fluids. It is expressed by a wide range of cell types and tissues, and its expression is regulated by different mechanisms in a cell type-specific manner.
\end{abstract}

IGFBP-4 binds IGF-I and IGF-II with similar affinities and inhibits their actions under almost all in vitro and in vivo conditions. In this review, we summarize the available data regarding the following aspects of IGFBP-4: genomic organization, protein structure-function relationship, expression and its regulation, as well as IGFdependent and -independent actions. The biological significance of IGFBP-4 for reproductive physiology, bone formation, renal pathophysiology and cancer is discussed. Journal of Endocrinology (2003) 178, 177-193

\section{Introduction}

Insulin-like growth factors (IGF-I and IGF-II), two growth-promoting peptides, have both mitogenic and metabolic actions that are involved in growth, survival and differentiation of many cell types and tissues under different physiological and pathological situations (reviews: Cohick \& Clemmons 1993, Stewart \& Rotwein 1996). IGFs can act in both an endocrine and a paracrine/ autocrine manner (reviews: Cohick \& Clemmons 1993, Mohan et al. 1996, Stewart \& Rotwein 1996, Butler \& LeRoith 2001). Gene-targeting studies in mice have demonstrated that both IGF-I and IGF-II are essential for growth and development (Liu et al. 1993, Liu et al. 1998, Butler \& LeRoith 2001).

The IGFs interact with specific cell surface receptors, designated type I and type II IGF receptors (IGF-IR and IGF-IIR). Most of the actions of IGF-I and IGF-II are mediated by the IGF-IR, which is a transmembrane receptor with tyrosine kinase activity (reviews: LeRoith et al. 1995, LeRoith 2000, De Meyts \& Whittaker 2002). IGF-IIR binds IGF-II with high affinity but interacts minimally with IGF-I (review: Braulke 1999). Gene- targeting studies revealed that IGF-IIR is important for the control of embryonic growth, and for internalization and degradation of extracellular IGF-II (reviews: Braulke 1999, Hassan 2003); however, it is unclear whether this receptor is involved in IGF-II signaling. IGF-IIR is identical to the cation-independent mannose-6-phosphate (Man-6-P) receptor that is involved in transport of Man-6-P-bearing lysosomal enzymes from their sites of synthesis into an endosomal/pre-lysosomal compartment (reviews: Braulke 1999, Hassan 2003).

The IGFs in serum and other extracellular environments are bound to specific IGF-binding proteins (IGFBPs), which represent a family of six secreted proteins with a common domain organization. They all have an N-terminal domain with 12 conserved Cys residues, a $\mathrm{C}$-terminal domain with six conserved Cys residues, and a central (L) domain with no Cys residues except in IGFBP-4 (review: Duan 2002). The N- and C-domains are at least 50\% homologous among the six IGFBPs in a given species, and for each IGFBP there is roughly $80 \%$ homology among different vertebrate species. The L-domain shows little similarity between species (reviews: Rechler 1993, Kelley et al. 1996). Since the affinities of 
IGFBPs for the IGFs are equal to or greater than those of the IGF receptors, several mechanisms have evolved which decrease IGFBP affinities and increase IGF bioavailability to the receptors. These mechanisms include phosphorylation, glycosylation, proteolysis and the adherence to the cell surface or extracellular matrix (ECM) (reviews: Jones \& Clemmons 1995, Clemmons 1997).

Recently, several so-called IGFBP-related proteins (IGFBP-rPs) have been discovered, which exhibit structural homology to the $\mathrm{N}$-terminal region of the classical IGFBPs, but have substantially lower affinities for IGFs (review: Hwa et al. 1999). The functional significance of the IGFBP-rPs for the IGF system is currently unclear.

IGFBPs have a plethora of functions. In addition to acting as carrier proteins, IGFBPs have been shown to inhibit or potentiate IGF actions. In serum and other biological fluids, IGFBPs modulate the endocrine actions of IGFs by regulating the bioavailability of IGFs for their receptors. IGFBPs are also expressed locally in a broad spectrum of tissues and act as autocrine/paracrine regulators of IGF effects. Furthermore, some IGFBPs have been demonstrated to have IGF-independent actions (reviews: Murphy 1998, Wetterau et al. 1999, Mohan \& Baylink 2002).

Among the six IGFBPs, IGFBP-4 is the smallest and is unique in that it has been consistently shown to inhibit IGF actions (Wetterau et al. 1999). IGFBP-4 was first described on the basis of its ability to potently inhibit bone cell growth (Mohan et al. 1989) and follicle-stimulating hormone-stimulated steroid production of ovarian granulosa cells ( $\mathrm{Ui}$ et al. 1989). The most likely mechanism is binding of secreted IGFs, preventing their interaction with IGF receptors (Mohan et al. 1995b). However, possible IGF-independent pathways of IGFBP-4 action have also been discussed (Singh et al. 1994, Perks et al. 1999, Wright et al. 2002).

In this review, we summarize the present knowledge of the genomic organization of the IGFBP-4 gene, structure-function relationships of IGFBP-4, IGFBP-4 expression and its regulation, as well as the IGF-dependent and -independent actions of IGFBP-4. The biological significance of IGFBP-4 is also discussed.

\section{Genomic organization of the IGFBP-4 gene}

The human IGFBP4 gene is located on chromosome 17 (Allander et al. 1993) and spans about $15 \cdot 3 \mathrm{~kb}$ (Zazzi et al. 1998). According to the mouse genome sequence determined so far, the mouse Igfbp 4 gene spans $11 \cdot 3 \mathrm{~kb}$ on chromosome 11 (http://www.ncbi.nlm.nih.gov/ LocusLink/LocRpt.cgi?l=16010). The rat Igfbp 4 gene spans at least $12 \mathrm{~kb}$ of genomic sequence (Gao et al. 1993). The genes for human IGFBP-4 (hIGFBP-4) and rat IGFBP-4 (rIGFBP-4) are composed of four exons separated by three introns, which give them an arrangement similar to the genes of the other IGFBPs except for
IGFBP-3 (Cubbage et al. 1990). The splice sites are highly conserved between human IGFBP 4 and rat Igfbp 4 genes, but the sizes of the introns vary slightly between the two species (Zazzi et al. 1998). Cell type-specific transcript sizes were documented in mouse cell lines which, when translated, suggest an additional non-IGF-binding variant present in mouse cells (Glantschnig et al. 1998).

Alignment of the published rat (Gao et al. 1993), human (Dai et al. 1997, Zazzi et al. 1998) and mouse (Glantschnig et al. 1998) IGFBP-4 promoter sequences revealed an overall high evolutionary conservation, but some promoter regions show less conservation and vary between the three species. It is interesting that the human sequence differs from rodent sequences by a $12 \mathrm{bp}$ insertion upstream to the transcription initiation codon (Dai et al. 1997). The IGFBP-4 promoter possesses a typical TATA box and a CAAT box. Several potential regulatory elements, such as cAMP responsive elements, steroid responsive elements, AP-1-binding sites and Sp1-binding sites exist in the IGFBP-4 5'-flanking regions of the three species (Gao et al. 1993, Dai et al. 1997, Glantschnig et al. 1998, Zazzi et al. 1998). These cis-regulatory binding sites provide the targets for a variety of local and systemic factors such as cAMP, parathyroid hormone (PTH) and various ligands of the steroid hormone receptor superfamily (such as glucocorticoids, retinoic acid, triiodothyronine, vitamin D), to regulate the expression of IGFBP-4 as discussed below.

Several $A l u$ repeat sequences are clustered in the proximity (upstream) of the human IGFBP4 gene, with an average of one Alu sequence per kb (Zazzi et al. 1998), which is a higher frequency than the normal distribution in the human genome (Houck et al. 1979). This indicates that the IGFBP4 gene is a hot spot for Alu integration. High-density Alu regions are often sites of genomic instability (Calabretta et al. 1982) and show a higher frequency of sequence polymorphism (Batzer \& Deininger 2002). Apart from the Alu repeat sequences, several polymorphic microsatellites were found within the boundaries of the human IGFBP4 gene (Zazzi et al. 1998). One of these was used as a marker to locate the hereditary breast-ovarian cancer gene (Tonin et al. 1993). Another highly polymorphic microsatellite was found in the first intron of the human IGFBP4 gene (Zazzi et al. 1998).

A typical cleavage site for poly(A) was found at the 3 '-end of the human IGFBP4 gene; however, no conserved poly(A) addition signal was detected within the 30 bp upstream region. Nevertheless, within this region an AAAAAA and several AACAAA consensus sequences were found, which could form a degenerate poly(A) addition signal. The few described eukaryotic genes that do not contain a standard AAUAAA sequence are involved in alternative polyadenylation, but this does not seem to be the case for the human IGFBP4 gene, since no variation in mRNA length has been reported and no alternate polyadenylation site was found within the IGFBP4 gene (Zazzi et al. 1998). 


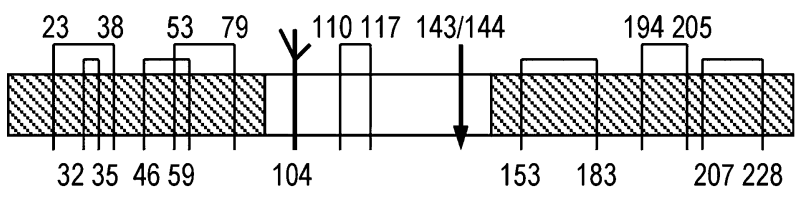

Figure 1 Structural features of hIGFBP-4. Numbers indicate cysteines involved in disulfide linkages (numbering based on the mature IGFBP-4 sequence derived from the prolGFBP-4 sequence containing a 21 aa signal peptide; SWISS-PROT accession number P22692). The conserved $\mathrm{N}$-terminal and C-terminal regions of hIGFBP-4 are shaded, and the non-conserved midregion is unshaded. Cysteines are indicated by vertical lines and disulfide linkages by horizontal lines. The $\mathrm{N}$-glycosylation site is shown by a trident and the PAPP-A cleavage site by an arrow.

\section{The protein: structure-function relationship}

hIGFBP-4 contains 237 amino acids (aa), and rIGFBP-4 consists of 233 aa. IGFBP-4 contains an N-linked glycosylation site and commonly exists in biological fluids as a doublet: a $24 \mathrm{kDa}$ non-glycosylated form and a $28 \mathrm{kDa}$ glycosylated form (Wetterau et al. 1999). IGFBP-4 is unique among the six IGFBPs in having two extra Cys residues in the variable L-domain encoded by exon 2 (Landale et al. 1995), which are linked to each other (Fig. 1) (Chelius et al. 2001). These unique properties of IGFBP-4 may be responsible for the distinctive biological behavior of this binding protein, i.e. solely inhibitory actions and lack of cell surface association.

\section{IGF binding}

IGFBP-4 inhibits IGF actions by preventing the binding of IGFs to their receptors. The binding of IGFBP-4 to IGFs is essential for this inhibitory effect (Mohan et al. 1995b, Miyakoshi et al. 1999). The IGF-binding domain may represent the major structural determinant of the biological activity of IGFBP-4. Therefore, elucidation of the structural determinants of various IGFBPs in IGF binding is important to the general understanding of the biology of the IGF system and may shed light on how these different IGFBPs exhibit specific actions.

It is generally accepted that the IGF-binding site for the various high-affinity IGFBPs is located in the N-terminal region. Mutational analysis indicated that the IGF-binding activity of hIGFBP-4 is mainly determined by the N-terminal region $\mathrm{Leu}^{72}-\mathrm{Ser}^{91}$, and to a lesser extent by the C-terminal region $\mathrm{Cys}^{205}-\mathrm{Val}^{214}$ (Qin et al. 1998). Although the three-dimensional structure of most IGFBPs has not been determined, disulfide bridging in IGFBPs appears to be important for maintaining the secondary structure required for IGF binding, since all six IGFBPs contain conserved Cys residues in both the $\mathrm{N}$-terminal and the C-terminal regions and reduced IGFBPs exhibit little or no IGF-binding activity (Landale et al. 1995, Qin et al. 1998, Neumann \& Bach 1999). Direct evidence was provided by disruption of the disulfide linkages in the $\mathrm{N}$-domain of rIGFBP-3, which resulted in complete loss of IGF-binding ability (Hashimoto et al. 1997). There is evidence suggesting that the IGF-binding domain in hIGFBP-4 involves a hydrophobic motif $\left(\mathrm{Leu}^{72}-\mathrm{Met}^{80}\right)$ located in the distal part of the conserved $\mathrm{N}$-terminal region, and that the N-terminal Cys residues (Cys9 and Cys12) are more critical than the C-terminal Cys residues (Cys17 and Cys20) for IGF binding (Byun et al. 2001a). Eight disulfide linkages in rIGFBP-4 and hIGFBP-4 have been determined, four in the $\mathrm{N}$-terminal (two of them are present in all six IGFBPs), three in the C-terminal (present in IGFBP-2 and -6 as well) and one in the midregion (Fig. 1) (Chelius et al. 2001).

Although the IGF binding is mainly determined by the $\mathrm{N}$-terminal conserved Cys residues, the six conserved C-terminal Cys residues in IGFBP-4 are essential for high-affinity binding of IGFs (Qin et al. 1998, Standker et al. 2000, Byun et al. 2001a). There is also evidence that in IGFBP-3 (Spencer \& Chan 1995) and IGFBP-2 (Forbes et al. 1998, Wang et al. 1988) the C-terminal region plays an important role in IGF binding. The six C-terminal Cys residues in IGFBP-4 are linked in the same manner as in IGFBP-2 and -6 (Chelius et al. 2001). Both IGFBP-2 and -6 share a binding preference for IGF-II and have the same C-terminal disulfide linkages, suggesting that a different disulfide linkage could conceivably influence IGF-II binding preference (Forbes et al. 1998). However, IGFBP-4 binds IGF-I and IGF-II with similar affinities; thus the highly conserved three C-terminal disulfide linkages either have no effect on the IGF-binding preference, or they are not the sole determinants.

\section{Cell surface association and tissue distribution}

Cell surface and ECM association is one of the possible mechanisms to alter the affinity of IGFBPs for the IGFs. Both IGFBP-1 and IGFBP-2 have an Arg-Gly-Asp (RGD) motif, which was shown to bind $\alpha 5 \beta 1$ integrin and consequently to mediate cell surface association of IGFBP-1 (Jones et al. 1993). We demonstrated that IGFBP-2 bound to the plasma membrane also in the absence of the RGD motif in IGFBP-2 (Hoeflich et al. 2002), indicating that additional mechanisms are involved in cell surface association of IGFBP-2. IGFBP-2 can bind to heparin, ECM and proteoglycans depending on the previous binding to IGF molecules (Arai et al. 1996, Russo et al. 1999). IGFBP-3 and -5 bind to distinct membrane receptors (Oh et al. 1993, Andress 1995, 1998, Leal et al. 1997). However, there is no evidence for cell surface association of IGFBP-4 (Kelley et al. 1996), suggesting that IGFBP-4 exists primarily in a soluble extracellular form.

When IGFBP-3 was perfused through the isolated, beating rat heart, it crossed the microvascular endothelium 
and was distributed primarily in cardiac muscle. In contrast, perfused IGFBP-4 also crossed the microvascular endothelium of the rat heart, but was preferentially distributed in connective tissue (Bar et al. 1990, Boes et al. 1992). A small basic C-terminal region (heparin-binding domain, HBD) of IGFBP-3 has been shown to be central to the ability of IGFBP-3 to bind to specific cells, such as endothelial cells (Booth et al. 1995, Knudtson et al. 2001). When this region was synthesized as an 18-mer peptide (P3), P3 bound to endothelial cells (Knudtson et al. 2001). IGFBP-4 lacks such an HBD and does not bind to endothelial cells (Booth et al. 1995). When the 20 C-terminal aa of IGFBP-4 region (P4) were replaced by the homologous $\mathrm{P} 3$ peptide, the generated chimeric IGFBP $-4_{3}$ bound specifically to endothelial cells, and it was distributed in the perfused rat heart similarly to the behavior of IGFBP-3 but different from that of IGFBP-4 (Knudtson et al. 2001), suggesting that the C-terminal region of IGFBP-4 is critical for its specific tissue distribution in the rat heart. These findings provide a novel potential mechanism of the tissue-specific actions of the IGFBPs.

\section{Glycosylation}

In 1991, Ceda and colleagues isolated two IGFBPs with apparent molecular weights (MW) of 28 and $24 \mathrm{kDa}$ from the conditioned medium of B104 rat neuroblastoma cells (Ceda et al. 1991). Sequence analysis revealed that both proteins had identical N-terminal sequences and appeared to be two forms of IGFBP-4. Treatment of these IGFBPs with endoglycosidase-F reduced the MW of the $28 \mathrm{kDa}$ IGFBP to $24 \mathrm{kDa}$. However, there was no change in the $24 \mathrm{kDa}$ IGFBP. The data from this and other studies (Cheung et al. 1991, Carr et al. 1994) demonstrated that IGFBP-4 exists as both N-glycosylated and nonglycosylated protein. Further analysis revealed that a single $\mathrm{N}$-linked glycosylation site is located in the midregion $\left(A s n^{104}\right)$ of hIGFBP-4 and rIGFBP-4 (Fig. 1) and that the glycosylation of IGFBP-4 does not affect its binding to IGFs (Chelius et al. 2001). Five different glycosylation isoforms of rIGFBP-4, isolated from rat serum, were recently identified (Chelius et al. 2002). All identified oligosaccharides are bi-antennary and differ only in the number of sialic acid terminal residues and/or core modification with fucose. The physiological significance of the glycosylation in IGFBP-4 is unknown.

\section{Proteolysis}

Proteolysis is a major regulatory mechanism of IGFBP-4 functions. Each of the six IGFBPs can undergo proteolysis, which results in decreased affinity for IGFs. While some of the IGFBP proteases can use multiple IGFBPs as substrate, there are apparently proteases that are specific for individual IGFBPs (reviews: Maile \& Holly 1999, Schneider et al. 2002). An IGF-dependent IGFBP-4-specific protease was first reported in the media conditioned by both human and sheep dermal fibroblasts (Fowlkes \& Freemark 1992), which was then identified as pregnancy-associated plasma protein-A (PAPP-A) (Lawrence et al. 1999b). This proteolytic activity has also been detected in the conditioned media from human osteoblasts (X Qin et al. 1999), vascular smooth muscle cells (Bayes-Genis et al. 2001), granulosa cells (Conover et al. 2001), trophoblast and decidualized endometrial stromal cells (Giudice $e t$ al. 2002), as well as in ovarian follicular fluid (Conover et al. 1999) and human pregnancy serum (Byun et al. 2001b).

PAPP-A was first isolated from human pregnancy serum (Lin et al. 1974) and belongs to the large metzincin family of metalloproteases (Lawrence et al. 1999a, Boldt et al. 2001). It cleaves IGFBP-4 at a single site, between $\mathrm{Met}^{135} / \mathrm{Lys}^{136}$ in hIGFBP-4 (Fig. 1) (Byun et al. 2000, Laursen et al. 2002a). IGFBP-4 cleavage by PAPP-A uniquely depends on the presence of IGF (Byun et al. 2000, Qin et al. 2000, Laursen et al. 2001). Recent data suggest that IGFs enhance the proteolysis by binding to IGFBP-4, but not by interaction with PAPP-A (Qin et al. 2000, Laursen et al. 2001). PAPP-A also cleaves hIGFBP-5 between $\mathrm{Ser}^{143} / \mathrm{Lys}^{144}$, which does not require the presence of IGF, but is slightly inhibited by IGF (Laursen et al. 2001, Rivera \& Fortune 2003). PAPP-A can cleave bovine IGFBP-2 between $\mathrm{Gln}^{165} / \mathrm{Met}^{166}$ as well, and this proteolytic activity was shown to be dose-dependently enhanced by IGFs (Monget et al. 2003). PAPP-A is secreted as a dimer of $400 \mathrm{kDa}$, but exists in human pregnancy serum as a $500 \mathrm{kDa}$ covalent heterotetrameric 2:2 complex with the proform of eosinophil major basic protein (proMBP), which functions as an inhibitor of the proteolytic activity of PAPP-A (Overgaard et al. 2000). The proMBP was also expressed in human fibroblasts after phorbol ester tumor promoter treatment and simian virus 40 transformation, and inhibited the proteolytic activity of IGFBP-4 (Chen et al. 2002). IGFBP-3, -5 and -6 can also function as inhibitors of IGFBP-4 proteolysis, probably through the homologous HBD in the C-termini of these IGFBPs (Fowlkes et al. 1997). A peptide derived from the HBD of IGFBP-5 (P5) is also able to inhibit the cleavage of IGFBP-2 by PAPP-A, and this inhibition is due to a direct interaction of P5 with PAPP-A rather than with IGFBP-2 (Monget et al. 2003). Recent data demonstrate that PAPP-A reversibly binds to the cell surface of several cell types, which does not affect the proteolytic activity of PAPP-A (Laursen et al. 2002b). This suggests that adhesion to the cell surface functions to target PAPP-A activity to the vicinity of the IGF receptor, decreasing the probability that released IGF is captured by other IGFBPs before receptor binding. Proteolysis of IGFBP-4 by PAPP-A enhances IGF bioavailability. Its physiological significance will be discussed below. 
Table 1 Regulatory mechanisms for IGFBP-4 expression in vivo

Tissue type/species

Agent

Clenbuterol

EB1089

Estrogen

$\mathrm{FSH}$

$\mathrm{GH}$

GHRA

GHRP-2

hCG

LPS

Nandrolone

PMSG

$\mathrm{T}_{3}$

$\mathrm{T}_{4}$
Soleus muscle/r

Prostate/r

Bone $/ \mathrm{m}$

Serum/constitutionally tall girls

Ovary/r

Serum/zinc-deprived rat

Serum/postmenopausal woman

Serum/bGH transgenic mice

Serum, liver/m

Plasma/b (high feed intake)

Plasma/b (low feed intake)

Mammary gland/r

Ovary/r

Serum $/ r$

Diaphragm muscle/r

Ovary/r

Kidney, serum/hypothyroid rat

Liver, serum/hypothyroid rat

Uterus/ $\mathrm{r}$

Liver, mammary gland/r
Effect

$\mathrm{S}$

$\mathrm{S}$

$\mathrm{S}$

$\mathrm{S}$

$\mathrm{S}$

S

$\mathrm{S}$

$\mathrm{S}$

n

i

$\mathrm{S}$

i

S

$\mathrm{S}$

$\mathrm{S}$

$\mathrm{S}$
Reference

Awede et al. 2002

Nickerson \& Huynh 1999

Lindberg et al. 2002

Rooman et al. 2002

Putowski et al. 1997

Ninh et al. 1998

Kassem et al. 1998

Blackburn et al. 1997

van Neck et al. 2000

Lee et al. 2000

Lee et al. 2000

Huynh 1998

Putowski et al. 1997

Soto et al. 1998

Lewis et al. 2002

Putowski et al. 1997

Voci et al. 2001

Demori et al. 1997b

Bottazzi et al. 1996

Rosato et al. 2002

EB1089, vitamin $\mathrm{D}_{3}$ analogue; FSH, follicle-stimulating hormone; $\mathrm{GH}$, growth hormone; GHRA, GH receptor antagonist; GHRP-2, GH-releasing peptide-2; hCG, human chorionic gonadotropin; LPS, lipopolysaccharide; PMSG, pregnant mare's serum gonadotropin; $T_{3}$, triiodothyronine; $T_{4}$, thyroxine; $b$, bovine; $h$, human; $m$, mouse; $r$, rat; $s$, stimulation; $i$, inhibition; n, no effect.

\section{IGFBP-4 expression in vivo and its regulation}

IGFBP-4 has been identified in all biological fluids, including serum, follicular fluid, seminal fluid, interstitial fluid and synovial fluid (Rajaram et al. 1997). It is the second most abundant IGFBP in adult rat serum after IGFBP-3. Northern blot analysis revealed that IGFBP-4 mRNA is widely expressed in adult rat tissues, including adrenal gland, testis, spleen, heart, liver, lung, kidney, stomach, hypothalamus and brain cortex, with liver being the site of the highest expression (Shimasaki et al. 1990). The expression of IGFBP-4 was also examined in rat small intestine (Shoubridge et al. 2001), smooth muscle (Smith et al. 2001), skeletal muscle (Jennische \& Hall 2000), pancreas (Hill et al. 1999), uterus and placenta (Cerro \& Pintar 1997), mouse spinal cord (Arnold et al. 2000), mouse and human thymus (Li et al. 1996), human prostate (Thomas et al. 2000), bone (Mohan et al. 1995a) and ovary (Zhou \& Bondy 1993, el Roeiy et al. 1994) of several species. In the mouse embryo, IGFBP-4 transcripts were detected as early as 11 days postcoitum (dpc) in different regions, including telencephalon, mesencephalon, snout, tongue and differentiating sclerotomes. After $14 \mathrm{dpc}$ IGFBP-4 mRNA was undetected in the brain, but clearly detectable in lung, liver, kidney, intestine, vertebrae, ribs and incisivi (Cerro et al. 1993, Schuller et al. 1993). IGFBP-4 protein was localized in telencephalon, mesencephalon, heart, liver, lung, tongue, blood vessels and kidney of 13.5 dpc mouse embryo by immunohistochemi- cal analysis (van Kleffens et al. 1999). These findings suggest that IGFBP-4 expression is developmentally regulated. Moreover, hormones, cytokines and other agents regulate the expression of IGFBP-4 in a tissuespecific manner (see Table 1).

\section{IGFBP-4 expression in vitro and its regulation}

Consistent with the widespread expression of IGFBP-4 in vivo, IGFBP-4 is expressed by various cell types in vitro, including fibroblasts, osteoblasts, myoblasts, epithelial cells, endothelial cells, chondrocytes and many kinds of tumor cells. The expression of IGFBP-4 in vitro is regulated by a large number of agents in a cell-specific manner. The effects of these agents are summarized in Table 2.

\section{Actions of IGFBP-4}

Several lines of evidence suggest that IGFBP-4 functions as a purely inhibitory protein in vitro and in vivo. These inhibitory actions can be exerted via IGF-dependent and -independent pathways (Fig. 2).

\section{IGF-dependent actions}

IGFBP-4 inhibits IGF-induced cell proliferation and differentiation in all cell types studied in vitro so far, including bone cells (Schiltz et al. 1993, Mohan et al. 1995b, Mohan \& Baylink 2002), muscle cells (Damon et al. 1998a, Ewton 
Table 2 Regulatory mechanisms for IGFBP-4 expression in vitro

Cell types/species

Agent

ACTH

ACTH and IGFs

Activin

Androgen

Angiotensin II

bFGF

cAMP

Dexamethasone

EGF

Estrogen

FSH

$\mathrm{GH}$

Glucagon

Glucose

IGF-I

IGF-II

IL-1 $\beta$

IL-6

IFN- $\gamma$

Insulin

Insulin + glucagon

$\mathrm{N}$-myc oncogene OP-1
Adrenocortical cells/h

Adrenocortical cells/h

Granulosa cells/r

Osteoblasts/h

Granulosa cells/h

Vascular smooth muscle cells/r

Multiple myeloma/h

Fetal lung fibroblasts/r

Multiple myeloma/h

Vascular smooth muscle cells/h

Osteoblasts $/ r$

L6 myoblasts/r

Articular chondrocytes/h

Bone marrow stromal cells $/ r$

Bone marrow stromal cells/h

Vascular smooth muscle cells/h

TC3 pancreatic beta cells

Fibroblasts/h,b

Fetal lung fibroblasts/ $r$

MCF-7 breast cancer cells/h

SaOS-2 osteoblasts/h

hFOB/ER9 osteoblasts/h

Granulosa cells/r

TC3 pancreatic beta cells

Ovarian thecal cells/b

Retinal endothelial cells/h

Retinal endothelial cells/h

Glomerular endothelial cells/h

Uterine myometrial cells

Smooth muscle cells $/ \mathrm{h}$

Vascular smooth muscle cells/r

Vascular smooth muscle cells/p

Vascular smooth muscle cells/h

L6 myoblasts/r

Fibroblasts/h

Fibroblasts/b

SH-SY5Y neuroblastoma cells $/ \mathrm{h}$

Bone marrow stromal cells/h

Adrenocortical cells/b

TC3 pancreatic beta cells

Non-small cell lung cancer cells

SH-SY5Y neuroblastoma cells/h

Ovarian granulosa cells

Articular chondrocytes/h

Fetal lung fibroblast/r

Hepatocytes/r

Multiple myeloma/h

Multiple myeloma/h

Ovarian thecal cells/b

L6 myoblasts/r

TC3 pancreatic beta cells

SH-SY5Y neuroblastoma cells/h

Granulosa cells/h

Ovarian thecal cells/b

SK-N-SH neuroblastoma cells/h

Osteoblasts/r
Reference

Fottner et al. 2001

Fottner et al. 2001

Choi et al. 1997

Gori et al. 1999

Greisen et al. 2002

Gustafsson et al. 1999b;

Anwar et al. 2000

Feliers et al. 1999

Price 1999

Felliers et al. 1999

Hayford et al. 1998

Chen et al. 1998

McCusker \& Clemmons 1998

Di Battista et al. 1997

Milne et al. 2001

Cheng et al. 1998

Hayford et al. 1998

Katz et al. 1997

Conover et al. 1995

Price 1999

C Qin et al. 1999

Kudo et al. 1996, 1997

Kassem et al. 1996

Piferrer et al. 1997

Katz et al. 1997

Chamberlain \& Spicer 2001

Giannini et al. 2001

Giannini et al. 2001

Giannini et al. 1999

Huynh 2000

Kuemmerle \& Teng 2000

Gustafsson et al. $1999 b$

Duan \& Clemmons 1998

Hayford et al. 1998

McCusker \& Clemmons 1998

Conover et al. 1995

Conover et al. 1995

Babajko et al. 1997

Thomas et al. 1999

Fottner et al. 1999

Katz et al. 1997

Fottner et al. 1999

Babajko et al. 1997

Chamoun et al. 1999

Di Battista et al. 1997

Price et al. 2002

Fernandez-Celemin \& Thissen 2001

Feliers et al. 1999

Feliers et al. 1999

Chamberlain \& Spicer 2001

McCusker \& Clemmons 1998

Katz et al. 1997

Babajko et al. 1997

Greisen et al. 2002

Chamberlain \& Spicer 2001

Chambery et al. 1999

Yeh et al. 1996 
Table 2 Continued

Cell types/species

Agent

PDGF-BB

PTH

RA

$\mathrm{T}_{3}$

TGF- $\alpha$

TGF- $\beta 1$

Thrombin

TNF- $\alpha$

$\mathrm{D}_{3}$ WT-1
Fetal lung fibroblasts/r

Multiple myeloma/h

Articular chondrocytes/h

SaOS-2 osteoblasts/h

SaOS-2 osteoblasts/h

TE85 osteosarcoma cells/h

Sertoli cells/p

Neuroblastoma cells/h

Osteoblasts/m

HT-29 colon carcinoma cells

Bone marrow stromal cells $/ r$

Sertoli cells/p

Primary hepatocytes/ $\mathrm{r}$

HepG2 hepatoma cells/h

Osteoblasts/m

Granulosa cells/r

Glomerular endothelial cells/h

Multiple myeloma/h

Stromal-vascular cells/p

Vascular smooth muscle cells $/ r$

Multiple myeloma/h

Fetal lung fibroblasts/r

Bone marrow stromal cells/h

Embryonic stem cells $/ \mathrm{m}$
Effect

n

$\mathrm{s}$

$\mathrm{S}$

$\mathrm{s}$

i

$\mathrm{S}$

$\mathrm{S}$

$\mathrm{S}$

$\mathrm{S}$

$\mathrm{S}$

$\mathrm{n}$

$\mathrm{s}$

$\mathrm{S}$

$\mathrm{s}$

$\mathrm{s}$

i

n

$\mathrm{s}$
Reference

Price 2001

Feliers et al. 1999

Di Battista et al. 1997

Kudo et al. 1996, 1997

Kudo et al. 1996, 1997;

LaTour et al. 1990

Honda et al. 1996

Bardi et al. 1999

Chambery et al. 1998

Glantschnig et al. 1996

Corkins et al. 2002

Milne et al. 2001

Bardi et al. 1999

Demori et al. 1997a,b

Demori et al. 1997a

Glantschnig et al. 1996

Piferrer et al. 1997

Giannini et al. 1999

Feliers et al. 1999

Richardson et al. 1998

Anwar et al. 2000

Feliers et al. 1999

Price et al. 2002

Kveiborg et al. 2001

Wagner et al. 2001

ACTH, adrenocorticotropic hormone; bFGF, basic fibroblast growth factor; CAMP, cyclic adenosine monophosphate; $\mathrm{EGF}$, epidermal growth factor; $\mathrm{FSH}$, follicle-stimulating hormone; $\mathrm{GH}$, growth hormone; IL, interleukin; IFN, interferon; OP-1, osteogenic protein-1; PDGF-BB, platelet-derived growth factor-BB; PTH, parathyroid hormone; RA, retinoic acid; $\mathrm{T}_{3}$, triiodothyronine; TGF, transforming growth factor; TNF, tumor necrosis factor; $\mathrm{D}_{3}, 1,25$-dihydroxyvitamin $\mathrm{D}_{3} ; \mathrm{WT}-1, \mathrm{~W}$, Wilms tumor-1 protein; $b$, bovine; $h$, human; $m$, mouse; $p$, porcine; $r$, rat; $s$, stimulation; $i$, inhibition; $n$, no effect.

et al. 1998, Gustafsson et al. 1999a), B104 rat neuroblastoma cells (Cheung et al. 1991), HT-29 human colon adenocarcinoma cells (Culouscou \& Shoyab 1991) and M12 human prostate cancer cells (Damon et al. 1998b). These inhibitory actions of IGFBP-4 have been demonstrated to be IGF-dependent on the basis of the following facts: (i) IGFBP-4 had no effect or lower potency in blocking the biological activity of IGF analogues which have significantly ( $>100$-fold) reduced binding affinity to IGFBP-4 (Mohan et al. 1995b); and (ii) IGFBP-4 inhibited the binding of IGF-I to purified IGF-IR in vitro (Mohan et al. 1995b).

Consistent with the in vitro data, IGFBP-4 is also a functional antagonist of IGF actions in vivo. For example, transgenic mice overexpressing IGFBP-4 selectively in smooth muscle cells exhibits smooth muscle hypoplasia (Wang et al. 1998, Zhang et al. 2002), which is in direct contrast to the smooth muscle hypertrophy induced by IGF-I overexpression (Wang et al. 1997). Moreover, a protease-resistant IGFBP-4 had more potency (Zhang et al. 2002) and IGF-I/IGFBP-4 double transgenic mice showed a reduction in wet weight of selected smooth muscle tissues (Wang et al. 1998), suggesting that these inhibitory effects of IGFBP-4 are IGF-I-dependent. In agreement with the above data, local administration of recombinant IGFBP-4 inhibited IGF-I-induced increases of bone formation in mice (Miyakoshi et al. 1999).

In contrast to local IGFBP-4 administration, systemic administration of IGFBP-4 increased bone formation (Miyakoshi et al. 1999, 2001). This was the only report regarding a growth-stimulatory effect of IGFBP-4, which was probably by increasing IGF bioavailability via an IGFBP-4 protease-dependent mechanism, since systemic administration of the native IGFBP-4, but not proteaseresistant IGFBP-4, increased the levels of serum free IGF-I, serum osteocalcin, serum and skeletal alkaline phosphatase, and IGFBP-4 proteolytic activity in serum (Miyakoshi et al. 2001).

\section{IGF-independent actions}

In addition to IGF-dependent actions, IGF-independent actions of IGFBP-4 have been suggested, based on the following findings: (i) IGFBP-4 caused a marked inhibition of ceramide-induced apoptosis of Hs578T human breast cancer cells, which lack a functional IGF-IR (Perks et al. 1999); (ii) IGFBP-4 inhibited human ovarian steroidogenesis in the presence of either the IGF-IR blocker 


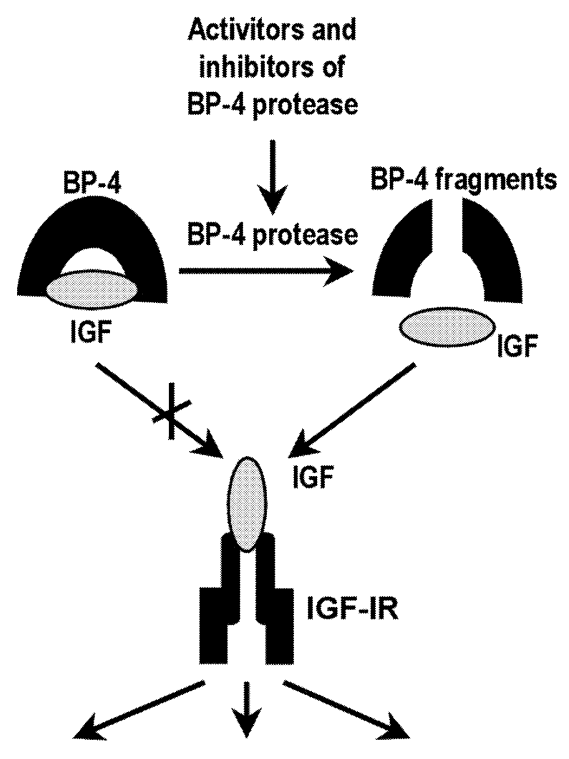

Survival Proliferation Differentiation

\section{Potential IGF-independent effects}

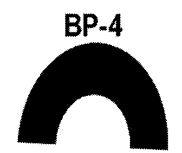

$?$

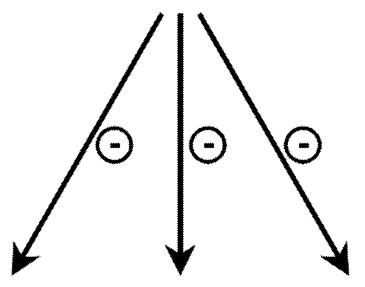

Apoptosis Steroidogenesis Mitogenisis

Figure 2 IGF-dependent and -independent actions of IGFBP-4 (BP-4). The mitogenic activity of IGFs, mediated by IGF-IR, is inhibited by the binding of IGFBP-4. Proteolysis of IGFBP-4 results in the release of IGFs from the IGF/IGFBP-4 complex and consequently a potentiation of IGF effects. Several potential IGF-independent effects of IGFBP-4 are also documented, but the mechanisms are unknown yet. Refer to the text for further details of these actions.

$\alpha$ IR 3 or excess IGFBP- 3 to remove the effects of endogenous IGF action (Wright et al. 2002); and (iii) endogenous IGFBP-4 inhibited the mitogenic effects of IGF and insulin in HT-29 human colonic adenocarcinoma cells, which could not be compensated for by the addition of an excess of IGF-I and insulin, but by the addition of an antibody against IGFBP-4 (Singh et al. 1994). However, unlike IGFBP-3 and -5 , a specific receptor for IGFBP-4 has not been identified yet. Further studies are necessary to define the mechanisms of IGF-independent actions of IGFBP-4.

\section{Biological significance of IGFBP-4}

\section{Reproductive physiology}

The expression pattern of IGFBP-4 and its regulation were extensively studied in human and animal reproductive organs at various reproductive stages. The findings in these studies indicate important roles for IGFBP-4 in reproduction.

Pregnancy IGFs, as mitogenic peptides, are important for fetal and placental growth during pregnancy (Han \& Carter 2000). In the human placenta, IGFs regulate syncytiotrophoblast steroidogenesis (Nestler 1987, 1990), glucose and amino acid transport in the villi (Kniss et al.
1994) and the invasion of the extravillous trophoblast into the maternal decidua (Han et al. 1996, McKinnon et al. 2001). IGFBPs are expressed by the maternal decidua and may regulate IGF actions during pregnancy (Han et al. 1996). In this context IGFBP-4 is particularly interesting for several reasons: (i) IGFBP-4 is the second most abundant IGFBP in the placental bed (Han et al. 1996); (ii) PAPP-A, an IGF-dependent IGFBP-4 protease, is secreted by human trophoblast cells and decidualized endometrial stroma (Giudice et al. 2002, Sun et al. 2002) and is markedly increased in the maternal circulation as pregnancy progresses (Byun et al. 2000); and (iii) in human pregnancy serum the majority of PAPP-A $(>99 \%)$ is found as a PAPP-A/proMBP complex (Oxvig et al. 1993). During pregnancy, rapid placental development and fetal growth obviously increases the need for growth-promoting factors such as IGFs. The mitogenic activity of IGFs at the local cellular level depends on the concentration of free IGFs that are able to interact with their receptors. The increased IGFBP-4 proteolytic activity resulting from uncomplexed PAPP-A may be required locally to increase the concentration of free IGFs for placental development and therefore for fetal growth during pregnancy, whereas the PAPP-A activity in maternal circulation is inhibited by complex formation with proMBP. The absence of PAPP-A expression in the placenta of pregnant patients with Cornelia de Lange syndrome, a condition involving incomplete fetal development and subsequent deformities 
(Westergaard et al. 1983), provides direct evidence for a role of PAPP-A in pregnancy. However, the roles of this complex system of enzyme (PAPP-A), substrate (IGFBP-4), inhibitor (proMBP) and cofactor (IGF-II) in the placenta and maternal circulation during human pregnancy deserve further investigation.

Different from human, recent data showed that the IGFBP-4 proteolytic activity in murine serum is not increased during pregnancy, eventually due to the lower level of PAPP-A expression in the placenta (Qin et al. 2002, Soe et al. 2002). The significance of this difference between species is unknown, but this difference must be taken into consideration when the mouse is used as a model organism for the study of PAPP-A function.

Ovarian physiology IGFs are produced by ovarian granulosa and theca cells, and mediate gonadotropin actions on ovarian cellular steroidogenesis and growth (Poretsky et al. 1999). Regulation of IGF actions within the ovarian follicle is particularly important in the processes of ovarian follicle development and follicle atresia (Monget et al. 2002). As a potent inhibitor of IGF actions, IGFBP-4 appears to be particularly important in ovarian physiology (Iwashita et al. 1996, Poretsky et al. 1999). High levels of IGFBP-4 are present in small androgen-dominant follicles (Zhou \& Bondy 1993, el Roeiy et al. 1994) and in follicular fluid from androgen-dominant follicles $\left(\mathrm{FF}_{\mathrm{a}}\right)$ that are growth-arrested or atretic (Cataldo \& Giudice 1992, San Roman \& Magoffin 1993). In contrast, IGFBP-4 is undetected by ligand blot analysis in follicular fluid from estrogen-dominant growing follicles $\left(\mathrm{FF}_{\mathrm{e}}\right)$. IGFBP-4 inhibits human ovarian steroidogenesis in vivo (Mason et al. 1998, Wright et al. 2002), and it has been suggested that IGFBP-4 inhibits follicle development by inhibiting IGF actions in the ovary, and conversely, the loss of this inhibitory factor allows for increased bioavailable IGFs, which coincides with selection of the dominant follicle (Poretsky et al. 1999). The complexity of this process has become even more apparent with the finding of the IGFBP-4-specific protease PAPP-A activity in $\mathrm{FF}_{\mathrm{e}}$, but not in $\mathrm{FF}_{\mathrm{a}}$ (Chandrasekher et al. 1995). PAPP-A is expressed in human and mouse ovaries, being restricted to healthy granulosa cells and granulosa-lutein cells (Hourvitz et al. 2000, 2002). This restricted expression pattern and its co-expression with aromatase and luteinizing hormone receptor in granulosa cells from preovulatory follicles suggests that PAPP-A could be considered as a functional marker of follicular development (Mazerbourg et al. 2001). During terminal development of follicles to the preovulatory stage, the degradation of IGFBP-4 by PAPP-A in the ovary may increase IGF bioavailability that further stimulates granulosa cell proliferation and steroidogenesis, and then actively participates in the selection of dominant follicles in vivo. In contrast, in atretic follicles, IGFBP-4 degradation is inhibited by locally increased IGFBP-2 and -5 that contain an HBD in their C-terminal regions (Mazerbourg et al. 2000). The IGFBP-4 protease activity has been reported in human, ovine, bovine, porcine, equine (Mazerbourg et al. 2000, 2001) and murine ovaries (Hourvitz et al. 2002), suggesting a wellconserved process for this protease in ovarian function.

\section{Bone formation}

IGFs are the most abundant growth factors stored in the bone and regulate the proliferation and differentiation of bone cells (Bautista et al. 1990). As in other tissues, the local activity of IGFs in bone is modulated by IGFBPs. IGFBP-4 is one of the major IGFBPs produced by bone cells (Mohan et al. 1995b) and has been proposed to function as an important regulator of bone formation. Evidence was provided by the following findings: (i) IGFBP-4 inhibited both basal and IGF-induced cell proliferation of MC3T3-E1 mouse osteoblasts and untransformed normal human bone cells (Mohan et al. 1995b) and the growth of embryonic chicken pelvic cartilage in vitro (Schiltz et al. 1993); (ii) a single local administration of IGFBP-4 inhibited IGF-I-induced increases in bone formation, whereas systemic administration of IGFBP-4 alone increased serum and skeletal levels of bone formation markers (osteocalcin and alkaline phosphatase) in mice (Miyakoshi et al. 1999, 2001). The latter stimulatory effect resulted from an increase of IGF bioavailability in the circulation via an IGFBP-4 protease-dependent mechanism (Miyakoshi et al. 2001); (iii) the serum level of IGFBP-4 was shown to increase with aging and to correlate positively with serum PTH levels (Rajaram et al. 1997, Karasik et al. 2002). PTH upregulated IGFBP-4 expression in human osteoblasts in vitro, and serum IGFBP-4 levels were found to be increased during oral 1,25-dihydroxyvitamin $\mathrm{D}_{3}$ therapy in psoriasis patients. These findings suggest that during calcium deficiency, the increase in serum PTH and 1,25-dihydroxyvitamin $\mathrm{D}_{3}$ may not only stimulate bone resorption, but also inhibit bone formation by stimulating IGFBP-4 production in bone cells (Mohan et al. 1995a, Rajaram et al. 1997, Karasik et al. 2002); and (iv) sera from patients with chronic renal failure (CRF) usually contain high levels of IGFBP-4, which may contribute to decreased bone formation in renal osteodystrophy (Van Doorn et al. 2001).

\section{Renal pathophysiology}

IGFBP-4 is abundantly expressed in the kidney. A sitespecific expression pattern of IGFBP-4 during nephrogenesis was described in the human (Matsell et al. 1994), rat (G J Price et al. 1995) and mouse (LindenberghKortleve et al. 1997), suggesting specific roles for IGFBP-4 in renal development and physiology. In addition, changes in IGFBP-4 abundance may be associated with pathological processes of the kidney. Upregulation of IGFBP-4 levels in serum correlated with the degree of renal 
dysfunction and growth retardation of children with CRF (Ulinski et al. 2000, Van Doorn et al. 2001), while downregulation of renal IGFBP-4 expression was reported in growth hormone-induced rat hypersomatotrophy (Hise et al. 2001).

\section{IGFBP-4 and cancer}

IGFBP-4 is expressed in a range of cells of tumor origin, such as lung adenocarcinoma (W A Price et al. 1995), non-small-cell lung cancer (Noll et al. 1996), breast cancer (C Qin et al. 1999), colon carcinoma (Michell et al. 1997), follicular thyroid carcinoma (Bachrach et al. 1995), gastric cancer (Yi et al. 2001), glioma (Bradshaw et al. 1999), hepatoma (Scharf et al. 1998), myeloma (Feliers et al. 1999), neuroblastoma (Cheung et al. 1991, Babajko \& Binoux 1996), osteosarcoma (Mohan et al. 1995b) and prostate cancer (Srinivasan et al. 1996, Damon et al. 1998b, Drivdahl et al. 2001).

In vitro and in vivo studies suggest that IGFBP-4 plays an important role in the growth regulation of a variety of tumors, possibly by inhibiting autocrine IGF actions or by as yet unknown IGF-independent mechanisms. Notably, in Caco-2 human colon carcinoma cells expression of IGFBP-4 mRNA was correlated with cell differentiation, indicating growth inhibitory effects in that cellular system (Hoeflich et al. 1996). Proliferation, anchorageindependent growth and tumor development in athymic nude mice were inhibited by overexpression of IGFBP-4 in M12 prostate cancer cells. Apoptosis was increased in the IGFBP-4-overexpressing cells, probably due to sequestrating IGF ligands (Damon et al. 1998b). Blocking of IGFBP-4 with antibodies enhanced both basal and IGF-stimulated growth of HT-29 human colonic carcinoma cells in both an IGF-dependent and an IGFindependent manner (Singh et al. 1994). Recombinant IGFBP-4 caused marked inhibition of ceramide-induced apoptosis of Hs578T human breast cancer cells via an IGF-independent pathway (Perks et al. 1999).

\section{Conclusions}

IGFBP-4 is the smallest of the six high-affinity IGFBPs. It exists in both non-glycosylated and glycosylated forms in all biological fluids. IGFBP-4 is expressed by a large range of cell types and tissues, and its expression is affected by different mechanisms in a cell type-specific manner. IGFBP-4 binds IGF-I and IGF-II with similar affinities and inhibits their actions in almost all in vitro and in vivo conditions. IGF-independent actions have also been reported. Proteolysis is a major regulatory mechanism for IGFBP-4. An IGF-dependent IGFBP-4-specific protease has been identified, which plays important roles in regulating IGFBP-4 actions in reproductive physiology. In addition, IGFBP-4 is an important regulator for bone formation and renal pathophysiology. Further studies are necessary to address the following questions: (i) Can IGFBP-4 enhance IGF actions? (ii) What is the mechanism underlying the IGF-independent actions of IGFBP-4? (iii) What is the subcellular distribution of IGFBP-4? (iv) What are the specific roles for IGFBP-4 in vivo? Biochemical, molecular biological and transgenic approaches will widen our understanding of the nature of this binding protein.

\section{Acknowledgement}

$\mathrm{R}$ Zhou is a recipient of a grant from the German Academic Exchange Service (DAAD).

\section{References}

Allander SV, Bajalica S, Larsson C, Luthman H, Powell DR, Stern I, Weber G, Zazzi H \& Ehrenborg E 1993 Structure and chromosomal localization of human insulin-like growth factor-binding protein genes. Growth Regulation 3 3-5.

Andress DL 1995 Heparin modulates the binding of insulin-like growth factor (IGF) binding protein-5 to a membrane protein in osteoblastic cells. Journal of Biological Chemistry 270 28289-28296.

Andress DL 1998 Insulin-like growth factor-binding protein-5 (IGFBP-5) stimulates phosphorylation of the IGFBP-5 receptor. American Journal of Physiology 274 E744-E750.

Anwar A, Zahid AA, Phillips L \& Delafontaine P 2000 Insulin-like growth factor binding protein-4 expression is decreased by angiotensin II and thrombin in rat aortic vascular smooth muscle cells. Arteriosclerosis, Thrombosis, and Vascular Biology 20 370-376.

Arai T, Busby W Jr \& Clemmons DR 1996 Binding of insulin-like growth factor (IGF) I or II to IGF-binding protein-2 enables it to bind to heparin and extracellular matrix. Endocrinology 137 4571-4575.

Arnold PM, Ma JY, Citron BA, Zoubine MN \& Festoff BW 2000 Selective developmental regulation of gene expression for insulinlike growth factor-binding proteins in mouse spinal cord. Spine $\mathbf{2 5}$ 1765-1770.

Awede BL, Thissen JP \& Lebacq J 2002 Role of IGF-I and IGFBPs in the changes of mass and phenotype induced in rat soleus muscle by clenbuterol. American Journal of Physiology 282 E31-E37.

Babajko S \& Binoux M 1996 Modulation by retinoic acid of insulinlike growth factor (IGF) and IGF binding protein expression in human SK-N-SH neuroblastoma cells. European Journal of Endocrinology 134 474-480.

Babajko S, Leneuve P, Loret C \& Binoux M 1997 IGF-binding protein-6 is involved in growth inhibition in SH-SY5Y human neuroblastoma cells: its production is both IGF- and cell densitydependent. Journal of Endocrinology 152 221-227.

Bachrach LK, Nanto-Salonen K, Tapanainen P, Rosenfeld RG \& Gargosky SE 1995 Insulin-like growth factor binding protein production in human follicular thyroid carcinoma cells. Growth Regulation 5 109-118.

Bar RS, Clemmons DR, Boes M, Busby WH, Booth BA, Dake BL \& Sandra A 1990 Transcapillary permeability and subendothelial distribution of endothelial and amniotic fluid insulin-like growth factor binding proteins in the rat heart. Endocrinology 127 1078-1086.

Bardi G, Bottazzi C, Demori I \& Palmero S 1999 Thyroid hormone and retinoic acid induce the synthesis of insulin-like growth factor-binding protein-4 in prepubertal pig sertoli cells. European Journal of Endocrinology 141 637-643. 
Batzer MA \& Deininger PL 2002 Alu repeats and human genomic diversity. Nature Reviews. Genetics 3 370-379.

Bautista CM, Mohan S \& Baylink DJ 1990 Insulin-like growth factors I and II are present in the skeletal tissues of ten vertebrates. Metabolism 39 96-100.

Bayes-Genis A, Schwartz RS, Lewis DA, Overgaard MT, Christiansen M, Oxvig C, Ashai K, Holmes DR Jr \& Conover CA 2001 Insulin-like growth factor binding protein-4 protease produced by smooth muscle cells increases in the coronary artery after angioplasty. Arteriosclerosis, Thrombosis, and Vascular Biology 21 335-341.

Blackburn A, Dressendorfer RA, Blum WF, Erhard M, Brem G, Strasburger CJ \& Wolf E 1997 Interactions of insulin-like growth factor (IGF)-II and growth hormone in vivo: circulating levels of IGF-I and IGF-binding proteins in transgenic mice. European Journal of Endocrinology 137 701-708.

Boes M, Booth BA, Sandra A, Dake BL, Bergold A \& Bar RS 1992 Insulin-like growth factor binding protein (IGFBP) 4 accounts for the connective tissue distribution of endothelial cell IGFBPs perfused through the isolated heart. Endocrinology 131 327-330.

Boldt HB, Overgaard MT, Laursen LS, Weyer K, Sottrup-Jensen L \& Oxvig C 2001 Mutational analysis of the proteolytic domain of pregnancy-associated plasma protein-A (PAPP-A): classification as a metzincin. Biochemical Journal 358 359-367.

Booth BA, Boes M, Andress DL, Dake BL, Kiefer MC, Maack C, Linhardt RJ, Bar K, Caldwell EE, Weiler J et al. 1995 IGFBP-3 and IGFBP-5 association with endothelial cells: role of C-terminal heparin binding domain. Growth Regulation 5 1-17.

Bottazzi C, Demori I, Leone M \& Fugassa E 1996 Thyroid hormone affects rat uterine expression of IGF-I and IGFBP-4. Bollettino della Societa Italiana di Biologia Sperimentale 72 133-138.

Bradshaw SL, D’Ercole AJ \& Han VK 1999 Overexpression of insulin-like growth factor-binding protein-2 in C6 glioma cells results in conditional alteration of cellular growth. Endocrinology 140 $575-584$.

Braulke T 1999 Type-2 IGF receptor: a multi-ligand binding protein. Hormone and Metabolism Research 31 242-246.

Butler AA \& LeRoith D 2001 Minireview: tissue-specific versus generalized gene targeting of the IGF1 and IGF1R genes and their roles in insulin-like growth factor physiology. Endocrinology $\mathbf{1 4 2}$ $1685-1688$

Byun D, Mohan S, Kim C, Suh K, Yoo M, Lee H, Baylink DJ \& Qin X 2000 Studies on human pregnancy-induced insulin-like growth factor (IGF)-binding protein-4 proteases in serum: determination of IGF-II dependency and localization of cleavage site. Journal of Clinical Endocrinology and Metabolism 85 373-381.

Byun D, Mohan S, Baylink DJ \& Qin X 2001a Localization of the IGF binding domain and evaluation of the role of cysteine residues in IGF binding in IGF binding protein-4. Journal of Endocrinology 169 135-143.

Byun D, Mohan S, Yoo M, Sexton C, Baylink DJ \& Qin X $2001 b$ Pregnancy-associated plasma protein-A accounts for the insulin-like growth factor (IGF)-binding protein-4 (IGFBP-4) proteolytic activity in human pregnancy serum and enhances the mitogenic activity of IGF by degrading IGFBP-4 in vitro. Journal of Clinical Endocrinology and Metabolism 86 847-854.

Calabretta B, Robberson DL, Barrera-Saldana HA, Lambrou TP \& Saunders GF 1982 Genome instability in a region of human DNA enriched in Alu repeat sequences. Nature 296 219-225.

Carr JM, Grant PA, Francis GL, Owens JA, Wallace JC \& Walton PE 1994 Isolation and characterization of ovine IGFBP-4: protein purification and cDNA sequence. Journal of Molecular Endocrinology 13 219-236.

Cataldo NA \& Giudice LC 1992 Insulin-like growth factor binding protein profiles in human ovarian follicular fluid correlate with follicular functional status. Journal of Clinical Endocrinology and Metabolism 74 821-829.
Ceda GP, Fielder PJ, Henzel WJ, Louie A, Donovan SM, Hoffman AR \& Rosenfeld RG 1991 Differential effects of insulin-like growth factor (IGF)-I and IGF-II on the expression of IGF binding proteins (IGFBPs) in a rat neuroblastoma cell line: isolation and characterization of two forms of IGFBP-4. Endocrinology 128 2815-2824.

Cerro JA \& Pintar JE 1997 Insulin-like growth factor binding protein gene expression in the pregnant rat uterus and placenta. Developmental Biology 184 278-295.

Cerro JA, Grewal A, Wood TL \& Pintar JE 1993 Tissue-specific expression of the insulin-like growth factor binding protein (IGFBP) mRNAs in mouse and rat development. Regulatory Peptides 48 189-198.

Chamberlain CS \& Spicer LJ 2001 Hormonal control of ovarian cell production of insulin-like growth factor binding proteins. Molecular and Cellular Endocrinology 182 69-81.

Chambery D, de Galle B \& Babajko S 1998 Retinoic acid stimulates IGF binding protein (IGFBP)-6 and depresses IGFBP-2 and IGFBP-4 in SK-N-SH human neuroblastoma cells. Journal of Endocrinology 159 227-232.

Chambery D, Mohseni-Zadeh S, de Galle B \& Babajko S 1999 $\mathrm{N}$-myc regulation of type I insulin-like growth factor receptor in a human neuroblastoma cell line. Cancer Research 59 2898-2902.

Chamoun D, DeMoura MD, Levitas E, Resnick CE, Gargosky SE, Rosenfeld RG, Matsumoto T \& Adashi EY 1999 Transcriptional and posttranscriptional regulation of intraovarian insulin-like growth factor-binding proteins by interleukin-1 beta (IL-1 beta): evidence for IL-1 beta as an antiatretic principle. Endocrinology $\mathbf{1 4 0}$ 3488-3495.

Chandrasekher YA, Van Dessel HJ, Fauser BC \& Giudice LC 1995 Estrogen- but not androgen-dominant human ovarian follicular fluid contains an insulin-like growth factor binding protein-4 protease. Journal of Clinical Endocrinology and Metabolism 80 2734-2739.

Chelius D, Baldwin MA, Lu X \& Spencer EM 2001 Expression, purification and characterization of the structure and disulfide linkages of insulin-like growth factor binding protein-4. Journal of Endocrinology 168 283-296.

Chelius D, Wu SL \& Bondarenko PV 2002 Identification of N-linked oligosaccharides of rat insulin-like growth factor binding protein-4. Growth Hormone and IGF Research 12 169-177.

Chen BK, Overgaard MT, Bale LK, Resch ZT, Christiansen M, Oxvig C \& Conover CA 2002 Molecular regulation of the IGF-binding protein-4 protease system in human fibroblasts: identification of a novel inducible inhibitor. Endocrinology 143 1199-1205

Chen Y, Shu H, Ji C, Casinghino S, Kim K, Gundberg CM, Centrella M \& McCarthy TL 1998 Insulin-like growth factor binding proteins localize to discrete cell culture compartments in periosteal and osteoblast cultures from fetal rat bone. Journal of Cellular Biochemistry 71 351-362.

Cheng SL, Zhang SF, Mohan S, Lecanda F, Fausto A, Hunt AH, Canalis E \& Avioli LV 1998 Regulation of insulin-like growth factors I and II and their binding proteins in human bone marrow stromal cells by dexamethasone. Journal of Cellular Biochemistry 71 $449-458$.

Cheung PT, Smith EP, Shimasaki S, Ling N \& Chernausek SD 1991 Characterization of an insulin-like growth factor binding protein (IGFBP-4) produced by the B104 rat neuronal cell line: chemical and biological properties and differential synthesis by sublines. Endocrinology 129 1006-1015.

Choi D, Rohan RM, Rosenfeld RG, Matsumoto T, Gargosky SE \& Adashi EY 1997 Activin-attenuated expression of transcripts encoding granulosa cell-derived insulin-like growth factor binding proteins 4 and 5 in the rat: a putative antiatretic effect. Biology of Reproduction 56 508-515.

Clemmons DR 1997 Insulin-like growth factor binding proteins and their role in controlling IGF actions. Cytokine and Growth Factor Reviews 8 45-62. 
Cohick WS \& Clemmons DR 1993 The insulin-like growth factors. Annual Review of Physiology 55 131-153.

Conover CA, Clarkson JT \& Bale LK 1995 Effect of glucocorticoid on insulin-like growth factor (IGF) regulation of IGF-binding protein expression in fibroblasts. Endocrinology 136 1403-1410.

Conover CA, Oxvig C, Overgaard MT, Christiansen M \& Giudice LC 1999 Evidence that the insulin-like growth factor binding protein-4 protease in human ovarian follicular fluid is pregnancy associated plasma protein-A. Journal of Clinical Endocrinology and Metabolism 84 4742-4745.

Conover CA, Faessen GF, Ilg KE, Chandrasekher YA, Christiansen M, Overgaard MT, Oxvig C \& Giudice LC 2001 Pregnancyassociated plasma protein-A is the insulin-like growth factor binding protein-4 protease secreted by human ovarian granulosa cells and is a marker of dominant follicle selection and the corpus luteum. Endocrinology 1422155

Corkins MR, McQuade J, Schaffer BS \& MacDonald RG 2002 Insulin-like growth factor binding protein-4 expression is dependent on the carbohydrate in the media in HT-29 cells. Growth Hormone and IGF Research 12 184-192.

Cubbage ML, Suwanichkul A \& Powell DR 1990 Insulin-like growth factor binding protein-3. Organization of the human chromosomal gene and demonstration of promoter activity. Journal of Biological Chemistry 265 12642-12649.

Culouscou JM \& Shoyab M 1991 Purification of a colon cancer cell growth inhibitor and its identification as an insulin-like growth factor binding protein. Cancer Research 51 2813-2819.

Dai B, Widen SG, Mifflin R \& Singh P 1997 Cloning of the functional promoter for human insulin-like growth factor binding protein-4 gene: endogenous regulation. Endocrinology 138 332-343.

Damon SE, Haugk KL, Birnbaum RS \& Quinn LS 1998 a Retrovirally mediated overexpression of insulin-like growth factor binding protein 4: evidence that insulin-like growth factor is required for skeletal muscle differentiation. Journal of Cellular Physiology 175 109-120.

Damon SE, Maddison L, Ware JL \& Plymate SR $1998 b$ Overexpression of an inhibitory insulin-like growth factor binding protein (IGFBP), IGFBP-4, delays onset of prostate tumor formation. Endocrinology 139 3456-3464.

De Meyts P \& Whittaker J 2002 Structural biology of insulin and IGF1 receptors: implications for drug design. Nature Reviews. Drug Discovery 1 769-783.

Demori I, Bottazzi C, Arzani D, Voci A \& Fugassa E $1997 a$ Regulation of IGFBP-1 and -4 expression by triiodothyronine (T3) in cultured hepatocytes is cell- and gene-specific. Bollettino della Societa Italiana di Biologia Sperimentale 73 47-53.

Demori I, Bottazzi C, Voci A, Gallo G, Scharf JG \& Fugassa E 1997 b Tri-iodothyronine increases insulin-like growth factor binding protein-4 expression in rat hepatocytes. Journal of Endocrinology $\mathbf{1 5 4}$ 155-165.

Di Battista JA, Dore S, Morin N, He Y, Pelletier JP \& Martel-Pelletier J 1997 Prostaglandin E2 stimulates insulin-like growth factor binding protein-4 expression and synthesis in cultured human articular chondrocytes: possible mediation by $\mathrm{Ca}(++)$-calmodulin regulated processes. Journal of Cellular Biochemistry 65 408-419.

Drivdahl RH, Sprenger C, Trimm K \& Plymate SR 2001 Inhibition of growth and increased expression of insulin-like growth factorbinding protein-3 (IGFBP-3) and -6 in prostate cancer cells stably transfected with antisense IGFBP-4 complementary deoxyribonucleic acid. Endocrinology 142 1990-1998.

Duan C 2002 Specifying the cellular responses to IGF signals: roles of IGF-binding proteins. Journal of Endocrinology 175 41-54.

Duan C \& Clemmons DR 1998 Differential expression and biological effects of insulin-like growth factor-binding protein-4 and -5 in vascular smooth muscle cells. Journal of Biological Chemistry 273 16836-16842. el Roeiy A, Chen X, Roberts VJ, Shimasakai S, Ling N, LeRoith D, Roberts CT Jr \& Yen SS 1994 Expression of the genes encoding the insulin-like growth factors (IGF-I and II), the IGF and insulin receptors, and IGF-binding proteins-1-6 and the localization of their gene products in normal and polycystic ovary syndrome ovaries. Journal of Clinical Endocrinology and Metabolism 78 1488-1496.

Ewton DZ, Coolican SA, Mohan S, Chernausek SD \& Florini JR 1998 Modulation of insulin-like growth factor actions in L6A1 myoblasts by insulin-like growth factor binding protein (IGFBP)-4 and IGFBP-5: a dual role for IGFBP-5. Journal of Cellular Physiology 177 47-57.

Feliers D, Woodruff K \& Abboud S 1999 Potential role of insulin-like growth factor binding protein-4 in the uncoupling of bone turnover in multiple myeloma. British Journal of Haematology 104 715-722.

Fernandez-Celemin L \& Thissen JP 2001 Interleukin-6 stimulates hepatic insulin-like growth factor binding protein-4 messenger ribonucleic acid and protein. Endocrinology 142 241-248.

Forbes BE, Turner D, Hodge SJ, McNeil KA, Forsberg G \& Wallace JC 1998 Localization of an insulin-like growth factor (IGF) binding site of bovine IGF binding protein-2 using disulfide mapping and deletion mutation analysis of the C-terminal domain. Journal of Biological Chemistry 273 4647-4652.

Fottner C, Engelhardt D \& Weber MM 1999 Characterization of insulin-like growth factor binding proteins (IGFBPs) secreted by bovine adrenocortical cells in primary culture: regulation by insulin-like growth factors (IGFs) and adrenocorticotropin (ACTH). Hormone and Metabolism Research 31 203-208.

Fottner C, Engelhardt D, Elmlinger MW \& Weber MM 2001 Identification and characterization of insulin-like growth factor (IGF)-binding protein expression and secretion by adult human adrenocortical cells: differential regulation by IGFs and adrenocorticotropin. Journal of Endocrinology 168 465-474.

Fowlkes J \& Freemark M 1992 Evidence for a novel insulin-like growth factor (IGF)-dependent protease regulating IGF-binding protein-4 in dermal fibroblasts. Endocrinology 131 2071-2076.

Fowlkes JL, Thrailkill KM, George-Nascimento C, Rosenberg CK \& Serra DM 1997 Heparin-binding, highly basic regions within the thyroglobulin type-1 repeat of insulin-like growth factor (IGF)binding proteins (IGFBPs) $-3,-5$, and -6 inhibit IGFBP-4 degradation. Endocrinology 138 2280-2285.

Gao L, Ling N \& Shimasaki S 1993 Structure of the rat insulin-like growth factor binding protein-4 gene. Biochemical and Biophysical Research Communications 190 1053-1059.

Giannini S, Cresci B, Pala L, Ciucci A, Manuelli C, Fujita-Yamaguchi Y, Cappugi P \& Rotella CM 1999 Human glomerular endothelial cells IGFBPs are regulated by IGF-I and TGF-beta1. Molecular and Cellular Endocrinology 154 123-136.

Giannini S, Cresci B, Pala L, Ciucci A, Franchini A, Manuelli C, Fujita-Yamaguchi Y, Cappugi P, Zonefrati R \& Rotella CM 2001 IGFBPs modulate IGF-I- and high glucose-controlled growth of human retinal endothelial cells. Journal of Endocrinology 171 273-284.

Giudice LC, Conover CA, Bale L, Faessen GH, Ilg K, Sun I, Imani B, Suen LF, Irwin JC, Christiansen M et al. 2002 Identification and regulation of the IGFBP-4 protease and its physiological inhibitor in human trophoblasts and endometrial stroma: evidence for paracrine regulation of IGF-II bioavailability in the placental bed during human implantation. Journal of Clinical Endocrinology and Metabolism 87 2359-2366.

Glantschnig H, Varga F \& Klaushofer K 1996 Thyroid hormone and retinoic acid induce the synthesis of insulin-like growth factorbinding protein-4 in mouse osteoblastic cells. Endocrinology 137 281-286.

Glantschnig H, Varga F, Luegmayr E \& Klaushofer K 1998 Characterization of the mouse insulin-like growth factor binding protein 4 gene regulatory region and expression studies. DNA and Cell Biology 17 51-60. 
Gori F, Hofbauer LC, Conover CA \& Khosla S 1999 Effects of androgens on the insulin-like growth factor system in an androgen-responsive human osteoblastic cell line. Endocrinology 140 $5579-5586$

Greisen S, Flyvbjerg A, Ledet T \& Ovesen P 2002 Regulation of insulin-like growth factor binding protein secretion by human granulosa luteal cells in a polycystic ovary-like environment. Fertility and Sterility 78 162-168.

Gustafsson T, Andersson P \& Arnqvist HJ 1999a Different inhibitory actions of IGFBP-1, -2 and -4 on IGF-I effects in vascular smooth muscle cells. Journal of Endocrinology 161 245-253.

Gustafsson T, Andersson P, Chen Y, Magnusson JO \& Arnqvist HJ $1999 b$ Interaction of angiotensin II and the insulin-like growth factor system in vascular smooth muscle cells. American Journal of Physiology 277 H499-H507.

Han VK \& Carter AM 2000 Spatial and temporal patterns of expression of messenger RNA for insulin-like growth factors and their binding proteins in the placenta of man and laboratory animals. Placenta 21 289-305.

Han VK, Bassett N, Walton J \& Challis JR 1996 The expression of insulin-like growth factor (IGF) and IGF-binding protein (IGFBP) genes in the human placenta and membranes: evidence for IGF-IGFBP interactions at the feto-maternal interface. Journal of Clinical Endocrinology and Metabolism 81 2680-2693.

Hashimoto R, Ono M, Fujiwara H, Higashihashi N, Yoshida M, Enjoh-Kimura T \& Sakano K 1997 Binding sites and binding properties of binary and ternary complexes of insulin-like growth factor-II (IGF-II), IGF-binding protein-3, and acid-labile subunit. Journal of Biological Chemistry 272 27936-27942.

Hassan AB 2003 Keys to the hidden treasures of the mannose 6-phosphate/insulin-like growth factor 2 receptor. American Journal of Pathology 162 3-6.

Hayford K, Boes M, Dake BL \& Bar RS 1998 Regulations of IGF binding proteins in human aorta vascular smooth muscle cells by cAMP, dexamethasone and IGF-I. Growth Hormone and IGF Research 8 369-375.

Hill DJ, Hogg J, Petrik J, Arany E \& Han VK 1999 Cellular distribution and ontogeny of insulin-like growth factors (IGFs) and IGF binding protein messenger RNAs and peptides in developing rat pancreas. Journal of Endocrinology 160 305-317.

Hise MK, Salmanullah M, Tannenbaum GS \& Rohan RM 2001 mRNA expression of the IGF system in the kidney of the hypersomatotropic rat. Nephron 88 360-367.

Hoeflich A, Yang Y, Huber S, Rascher W, Koepf G, Blum WF, Heinz-Erian P, Kolb HJ \& Kiess W 1996 Expression of IGFBP-2, -3 , and -4 mRNA during differentiation of Caco-2 colon epithelial cells. American Journal of Physiology 271 E922-E931.

Hoeflich A, Reisinger R, Vargas GA, Elmlinger MW, Schuett B, Jehle PM, Renner-Muller I, Lahm H, Russo VC \& Wolf E 2002 Mutation of the RGD sequence does not affect plasma membrane association and growth inhibitory effects of elevated IGFBP-2 in vivo. FEBS Letters $\mathbf{5 2 3}$ 63-67.

Honda Y, Landale EC, Strong DD, Baylink DJ \& Mohan S 1996 Recombinant synthesis of insulin-like growth factor-binding protein-4 (IGFBP-4): development, validation, and application of a radioimmunoassay for IGFBP-4 in human serum and other biological fluids. Journal of Clinical Endocrinology Metabolism $\mathbf{8 1}$ 1389-1396.

Houck CM, Rinehart FP \& Schmid CW 1979 A ubiquitous family of repeated DNA sequences in the human genome. Journal of Molecular Biology 132 289-306.

Hourvitz A, Widger AE, Filho FL, Chang RJ, Adashi EY \& Erickson GF 2000 Pregnancy-associated plasma protein-A gene expression in human ovaries is restricted to healthy follicles and corpora lutea. Journal of Clinical Endocrinology and Metabolism 85 4916-4920.

Hourvitz A, Kuwahara A, Hennebold JD, Tavares AB, Negishi H, Lee TH, Erickson GF \& Adashi EY 2002 The regulated expression of the pregnancy-associated plasma protein-A in the rodent ovary: a proposed role in the development of dominant follicles and of corpora lutea. Endocrinology 143 1833-1844.

Huynh H 1998 In vivo regulation of the insulin-like growth factor system of mitogens by human chorionic gonadotropin. International Journal of Oncology 13 571-575.

Huynh H 2000 Post-transcriptional and post-translational regulation of insulin-like growth factor binding protein-3 and -4 by insulin-like growth factor-I in uterine myometrial cells. Growth Hormone and IGF Research 10 20-27.

Hwa V, Oh Y \& Rosenfeld RG 1999 The insulin-like growth factor-binding protein (IGFBP) superfamily. Endocrine Reviews 20 761-787.

Iwashita M, Kudo Y, Yoshimura Y, Adachi T, Katayama E \& Takeda Y 1996 Physiological role of insulin-like-growth-factor-binding protein-4 in human folliculogenesis. Hormone Research 46 (Suppl 1) $31-36$.

Jennische E \& Hall CM 2000 Expression and localisation of IGFbinding protein mRNAs in regenerating rat skeletal muscle. Acta Pathologica, Microbiologica et Immunologica Scandinavica 108 747-755.

Jones JI \& Clemmons DR 1995 Insulin-like growth factors and their binding proteins: biological actions. Endocrine Reviews 16 3-34.

Jones JI, Gockerman A, Busby WH Jr, Wright G \& Clemmons DR 1993 Insulin-like growth factor binding protein 1 stimulates cell migration and binds to the alpha 5 beta 1 integrin by means of its Arg-Gly-Asp sequence. PNAS 90 10553-10557.

Karasik D, Rosen CJ, Hannan MT, Broe KE, Dawson-Hughes B, Gagnon DR, Wilson PW, Visser M, Langlois JA, Mohan S et al. 2002 Insulin-like growth factor binding proteins 4 and 5 and bone mineral density in elderly men and women. Calcified Tissue International 71 323-328.

Kassem M, Okazaki R, De Leon D, Harris SA, Robinson JA, Spelsberg TC, Conover CA \& Riggs BL 1996 Potential mechanism of estrogen-mediated decrease in bone formation: estrogen increases production of inhibitory insulin-like growth factor-binding protein-4. Proceedings of the Association of American Physicians 108 155-164.

Kassem M, Brixen K, Mosekilde L, Blum WF \& Flyvbjerg A 1998 Effects of growth hormone treatment on serum levels of insulin-like growth factors (IGFs) and IGF binding proteins $1-4$ in postmenopausal women. Clinical Endocrinology 49 747-756.

Katz LE, Bhala A, Camron E, Nunn SE, Hintz RL \& Cohen P 1997 IGF-II, IGF-binding proteins and IGF receptors in pancreatic beta-cell lines. Journal of Endocrinology 152 455-464.

Kelley KM, Oh Y, Gargosky SE, Gucev Z, Matsumoto T, Hwa V, Ng L, Simpson DM \& Rosenfeld RG 1996 Insulin-like growth factor-binding proteins (IGFBPs) and their regulatory dynamics. International Journal of Biochemistry and Cell Biology 28 619-637.

Kniss DA, Shubert PJ, Zimmerman PD, Landon MB \& Gabbe SG 1994 Insulin-like growth factors. Their regulation of glucose and amino acid transport in placental trophoblasts isolated from first-trimester chorionic villi. Journal of Reproductive Medicine 39 249-256.

Knudtson KL, Boes M, Sandra A, Dake BL, Booth BA \& Bar RS 2001 Distribution of chimeric IGF binding protein (IGFBP)-3 and IGFBP-4 in the rat heart: importance of C-terminal basic region. Endocrinology 142 3749-3755.

Kudo Y, Iwashita M, Itatsu S, Iguchi T \& Takeda Y 1996 Regulation of insulin-like growth factor-binding protein-4 protease activity by estrogen and parathyroid hormone in SaOS-2 cells: implications for the pathogenesis of postmenopausal osteoporosis. Journal of Endocrinology $150223-229$.

Kudo Y, Iwashita M, Iguchi T, Takeda Y, Hizuka N, Takano K \& Muraki T 1997 Estrogen and parathyroid hormone regulate insulin-like growth factor binding protein-4 in SaOS-2 cells. Life Sciences 61 165-170. 
Kuemmerle JF \& Teng B 2000 Regulation of IGFBP-4 levels in human intestinal muscle by an IGF-I-activated, confluencedependent protease. American Journal of Physiology 279 G975-G982.

Kveiborg M, Flyvbjerg A, Eriksen EF \& Kassem M 2001 1,25-Dihydroxyvitamin D3 stimulates the production of insulin-like growth factor-binding proteins-2, -3 and -4 in human bone marrow stromal cells. European Journal of Endocrinology 144 549-557.

Landale EC, Strong DD, Mohan S \& Baylink DJ 1995 Sequence comparison and predicted structure for the four exon-encoded regions of human insulin-like growth factor binding protein 4 . Growth Factors 12 245-250.

LaTour D, Mohan S, Linkhart TA, Baylink DJ \& Strong DD 1990 Inhibitory insulin-like growth factor-binding protein:cloning, complete sequence, and physiological regulation. Molecular Endocrinology 4 1806-1814.

Laursen LS, Overgaard MT, Soe R, Boldt HB, Sottrup-Jensen L, Giudice LC, Conover CA \& Oxvig C 2001 Pregnancy-associated plasma protein-A (PAPP-A) cleaves insulin-like growth factor binding protein (IGFBP)-5 independent of IGF: implications for the mechanism of IGFBP-4 proteolysis by PAPP-A. FEBS Letters 504 36-40.

Laursen LS, Overgaard MT, Nielsen CG, Boldt HB, Hopmann KH, Conover CA, Sottrup-Jensen L, Giudice LC \& Oxvig C 2002a Substrate specificity of the metalloproteinase pregnancy-associated plasma protein-A (PAPP-A) assessed by mutagenesis and analysis of synthetic peptides: substrate residues distant from the scissile bond are critical for proteolysis. Biochemical Journal 367 31-40.

Laursen LS, Overgaard MT, Weyer K, Boldt HB, Ebbesen P, Christiansen M, Sottrup-Jensen L, Giudice LC \& Oxvig C $2002 b$ Cell surface targeting of pregnancy-associated plasma protein A proteolytic activity. Reversible adhesion is mediated by two neighboring short consensus repeats. Journal of Biological Chemistry 277 47225-47234.

Lawrence JB, Bale LK, Haddad TC, Clarkson JT \& Conover CA $1999 a$ Characterization and partial purification of the insulin-like growth factor (IGF)-dependent IGF binding protein-4-specific protease from human fibroblast conditioned media. Growth Hormone and IGF Research 9 25-34.

Lawrence JB, Oxvig C, Overgaard MT, Sottrup-Jensen L, Gleich GJ, Hays LG, Yates JR III \& Conover CA $1999 b$ The insulin-like growth factor (IGF)-dependent IGF binding protein-4 protease secreted by human fibroblasts is pregnancy-associated plasma protein-A. PNAS 96 3149-3153.

Leal SM, Liu Q, Huang SS \& Huang JS 1997 The type V transforming growth factor beta receptor is the putative insulin-like growth factor-binding protein 3 receptor. Journal of Biological Chemistry 272 20572-20576.

Lee HG, Vega RA, Phung LT, Matsunaga N, Kuwayama H \& Hidari H 2000 The effect of growth hormone-releasing peptide-2 (KP102) administration on plasma insulin-like growth factor (IGF)-1 and IGF-binding proteins in Holstein steers on different planes of nutrition. Domestic Animal Endocrinology 18 293-308.

LeRoith D 2000 Insulin-like growth factor I receptor signaling overlapping or redundant pathways? Endocrinology 141 1287-1288.

LeRoith D, Werner H, Beitner-Johnson D \& Roberts CT Jr 1995 Molecular and cellular aspects of the insulin-like growth factor I receptor. Endocrine Reviews 16 143-163.

Lewis MI, Horvitz GD, Clemmons DR \& Fournier M 2002 Role of IGF-I and IGF-binding proteins within diaphragm muscle in modulating the effects of nandrolone. American Journal of Physiology 282 E483-E490.

Li YM, Arkins S, McCusker RH Jr, Donovan SM, Liu Q, Jayaraman S, Dantzer R \& Kelley KW 1996 Macrophages synthesize and secrete a 25-kilodalton protein that binds insulin-like growth factor-I. Journal of Immunology 156 64-72.

Lin TM, Galbert SP, Kiefer D, Spellacy WN \& Gall S 1974 Characterization of four human pregnancy-associated plasma proteins. American Journal of Obstetrics and Gynecology 118 223-236.
Lindberg MK, Moverare S, Eriksson AL, Skrtic S, Gao H, Dahlman-Wright K, Gustafsson JA \& Ohlsson C 2002 Identification of estrogen-regulated genes of potential importance for the regulation of trabecular bone mineral density. Journal of Bone and Mineral Research 17 2183-2195.

Lindenbergh-Kortleve DJ, Rosato RR, van Neck JW, Nauta J, van Kleffens M, Groffen C, Zwarthoff EC \& Drop SL 1997 Gene expression of the insulin-like growth factor system during mouse kidney development. Molecular and Cellular Endocrinology 132 81-91.

Liu JL, Grinberg A, Westphal H, Sauer B, Accili D, Karas M \& LeRoith D 1998 Insulin-like growth factor-I affects perinatal lethality and postnatal development in a gene dosage-dependent manner: manipulation using the Cre/loxP system in transgenic mice. Molecular Endocrinology 12 1452-1462.

Liu JP, Baker J, Perkins AS, Robertson EJ \& Efstratiadis A 1993 Mice carrying null mutations of the genes encoding insulin-like growth factor I (IGF-1) and type 1 IGF receptor (IGF1R). Cell 75 59-72.

Maile LA \& Holly JM 1999 Insulin-like growth factor binding protein (IGFBP) proteolysis: occurrence, identification, role and regulation. Growth Hormone and IGF Research 9 85-95.

Mason HD, Cwyfan-Hughes S, Holly JM \& Franks S 1998 Potent inhibition of human ovarian steroidogenesis by insulin-like growth factor binding protein-4 (IGFBP-4). Journal of Clinical Endocrinology and Metabolism 83 284-287.

Matsell DG, Delhanty PJ, Stepaniuk O, Goodyear C \& Han VK 1994 Expression of insulin-like growth factor and binding protein genes during nephrogenesis. Kidney International 46 1031-1042.

Mazerbourg S, Zapf J, Bar RS, Brigstock DR \& Monget P 2000 Insulin-like growth factor (IGF)-binding protein-4 proteolytic degradation in bovine, equine, and porcine preovulatory follicles: regulation by IGFs and heparin-binding domain-containing peptides. Biology of Reproduction 63 390-400.

Mazerbourg S, Overgaard MT, Oxvig C, Christiansen M, Conover CA, Laurendeau I, Vidaud M, Tosser-Klopp G, Zapf J \& Monget P 2001 Pregnancy-associated plasma protein-A (PAPP-A) in ovine, bovine, porcine, and equine ovarian follicles: involvement in IGF binding protein 4 proteolytic degradation and mRNA expression during follicular development. Endocrinology 142 5243-5253.

McCusker RH \& Clemmons DR 1998 Role for cyclic adenosine monophosphate in modulating insulin-like growth factor binding protein secretion by muscle cells. Journal of Cellular Physiology 174 293-300.

McKinnon T, Chakraborty C, Gleeson LM, Chidiac P \& Lala PK 2001 Stimulation of human extravillous trophoblast migration by IGF-II is mediated by IGF type 2 receptor involving inhibitory G protein(s) and phosphorylation of MAPK. Journal of Clinical Endocrinology and Metabolism 86 3665-3674.

Michell NP, Dent S, Langman MJ \& Eggo MC 1997 Insulin-like growth factor binding proteins as mediators of IGF-I effects on colon cancer cell proliferation. Growth Factors 14 269-277.

Milne M, Quail JM, Rosen CJ \& Baran DT 2001 Insulin-like growth factor binding proteins in femoral and vertebral bone marrow stromal cells: expression and regulation by thyroid hormone and dexamethasone. Journal of Cellular Biochemistry 81 229-240.

Miyakoshi N, Richman C, Qin X, Baylink DJ \& Mohan S 1999 Effects of recombinant insulin-like growth factor-binding protein-4 on bone formation parameters in mice. Endocrinology 140 $5719-5728$

Miyakoshi N, Qin X, Kasukawa Y, Richman C, Srivastava AK, Baylink DJ \& Mohan S 2001 Systemic administration of insulin-like growth factor (IGF)-binding protein-4 (IGFBP-4) increases bone formation parameters in mice by increasing IGF bioavailability via an IGFBP-4 protease-dependent mechanism. Endocrinology 142 2641-2648.

Mohan S \& Baylink DJ 2002 IGF-binding proteins are multifunctional and act via IGF-dependent and -independent mechanisms. Journal of Endocrinology 175 19-31. 
Mohan S, Bautista CM, Wergedal J \& Baylink DJ 1989 Isolation of an inhibitory insulin-like growth factor (IGF) binding protein from bone cell-conditioned medium: a potential local regulator of IGF action. PNAS 86 8338-8342.

Mohan S, Farley JR \& Baylink DJ 1995 a Age-related changes in IGFBP-4 and IGFBP-5 levels in human serum and bone: implications for bone loss with aging. Progress in Growth Factor Research 6 465-473.

Mohan S, Nakao Y, Honda Y, Landale E, Leser U, Dony C, Lang K \& Baylink DJ 1995b Studies on the mechanisms by which insulin-like growth factor (IGF) binding protein-4 (IGFBP-4) and IGFBP-5 modulate IGF actions in bone cells. Journal of Biological Chemistry $27020424-20431$.

Mohan S, Baylink DJ \& Pettis JL 1996 Insulin-like growth factor (IGF)-binding proteins in serum - do they have additional roles besides modulating the endocrine IGF actions? Journal of Clinical Endocrinology and Metabolism 81 3817-3820.

Monget P, Fabre S, Mulsant P, Lecerf F, Elsen JM, Mazerbourg S, Pisselet C \& Monniaux D 2002 Regulation of ovarian folliculogenesis by IGF and BMP system in domestic animals. Domestic Animal Endocrinology 23 139-154.

Monget P, Mazerbourg S, Delpuech T, Maurel MC, Maniere S, Zapf J, Lalmanach G, Oxvig C \& Overgaard MT 2003 Pregnancy-associated plasma protein-A is involved in insulin-like growth factor binding protein-2 (IGFBP-2) proteolytic degradation in bovine and porcine preovulatory follicles: identification of cleavage site and characterization of IGFBP-2 degradation. Biology of Reproduction 68 77-86.

Murphy LJ 1998 Insulin-like growth factor-binding proteins: functional diversity or redundancy? Journal of Molecular Endocrinology 21 97-107.

Nestler JE 1987 Modulation of aromatase and P450 cholesterol side-chain cleavage enzyme activities of human placental cytotrophoblasts by insulin and insulin-like growth factor I. Endocrinology 121 1845-1852.

Nestler JE 1990 Insulin-like growth factor II is a potent inhibitor of the aromatase activity of human placental cytotrophoblasts. Endocrinology 127 2064-2070.

Neumann GM \& Bach LA 1999 The N-terminal disulfide linkages of human insulin-like growth factor-binding protein-6 (hIGFBP-6) and hIGFBP-1 are different as determined by mass spectrometry. Journal of Biological Chemistry 274 14587-14594.

Nickerson T \& Huynh H 1999 Vitamin D analogue EB1089-induced prostate regression is associated with increased gene expression of insulin-like growth factor binding proteins. Journal of Endocrinology $160223-229$.

Ninh NX, Maiter D, Lause P, Chrzanowska B, Underwood LE, Ketelslegers JM \& Thissen JP 1998 Continuous administration of growth hormone does not prevent the decrease of IGF-I gene expression in zinc-deprived rats despite normalization of liver GH binding. Growth Hormone and IGF Research 8 465-472.

Noll K, Wegmann BR, Havemann K \& Jaques G 1996 Insulin-like growth factors stimulate the release of insulin-like growth factorbinding protein-3 (IGFBP-3) and degradation of IGFBP-4 in nonsmall cell lung cancer cell lines. Journal of Clinical Endocrinology and Metabolism 81 2653-2662.

Oh Y, Muller HL, Lamson G \& Rosenfeld RG 1993 Insulin-like growth factor (IGF)-independent action of IGF-binding protein-3 in Hs578T human breast cancer cells. Cell surface binding and growth inhibition. Journal of Biological Chemistry 268 14964-14971.

Overgaard MT, Haaning J, Boldt HB, Olsen IM, Laursen LS, Christiansen M, Gleich GJ, Sottrup-Jensen L, Conover CA \& Oxvig C 2000 Expression of recombinant human pregnancyassociated plasma protein-A and identification of the proform of eosinophil major basic protein as its physiological inhibitor. Journal of Biological Chemistry 275 31128-31133.

Oxvig C, Sand O, Kristensen T, Gleich GJ \& Sottrup-Jensen L 1993 Circulating human pregnancy-associated plasma protein-A is disulfide-bridged to the proform of eosinophil major basic protein. Journal of Biological Chemistry 268 12243-12246.

Perks CM, Bowen S, Gill ZP, Newcomb PV \& Holly JM 1999 Differential IGF-independent effects of insulin-like growth factor binding proteins (1-6) on apoptosis of breast epithelial cells. Journal of Cellular Biochemistry 75 652-664.

Piferrer F, Li D, Shimasaki S \& Erickson GF 1997 Transforming growth factor-alpha stimulates insulin-like growth factor binding protein-4 (IGFBP-4) expression and blocks follicle-stimulating hormone regulation of IGFBP-4 production in rat granulosa cells. Molecular and Cellular Endocrinology 133 9-17.

Poretsky L, Cataldo NA, Rosenwaks Z \& Giudice LC 1999 The insulin-related ovarian regulatory system in health and disease. Endocrine Reviews 20 535-582.

Price GJ, Berka JL, Edmondson SR, Werther GA \& Bach LA 1995 Localization of mRNAs for insulin-like growth factor binding proteins 1 to 6 in rat kidney. Kidney International 48 402-411.

Price WA 1999 Peptide growth factors regulate insulin-like growth factor binding protein production by fetal rat lung fibroblasts. American Journal of Respiratory Cell and Molecular Biology 20 332-341.

Price WA 2001 PDGF-BB regulates IGF-mediated IGFBP-4 proteolysis in fetal lung fibroblasts. Experimental Lung Research 27 655-674.

Price WA, Moats-Staats BM \& Stiles AD 1995 Insulin-like growth factor-I (IGF-I) regulates IGFBP-3 and IGFBP-4 by multiple mechanisms in A549 human adenocarcinoma cells. American Journal of Respiratory Cell and Molecular Biology 13 466-476.

Price WA, Moats-Staats BM \& Stiles AD 2002 Pro- and antiinflammatory cytokines regulate insulin-like growth factor binding protein production by fetal rat lung fibroblasts. American Journal of Respiratory Cell and Molecular Biology 26 283-289.

Putowski L, Rohan RM, Choi DS, Scherzer WJ, Ricciarelli E, Mordacq J, Mayo KE \& Adashi EY 1997 Rat ovarian insulin-like growth factor binding protein-4: a hormone-dependent granulosa cell-derived antigonadotropin. Journal of the Society for Gynecologic Investigation 4 144-151.

Qin C, Singh P \& Safe S 1999 Transcriptional activation of insulinlike growth factor-binding protein-4 by 17 beta-estradiol in MCF-7 cells: role of estrogen receptor-Sp1 complexes. Endocrinology 140 2501-2508.

Qin X, Strong DD, Baylink DJ \& Mohan S 1998 Structure-function analysis of the human insulin-like growth factor binding protein-4. Journal of Biological Chemistry 273 23509-23516.

Qin X, Byun D, Strong DD, Baylink DJ \& Mohan S 1999 Studies on the role of human insulin-like growth factor-II (IGF-II)-dependent IGF binding protein (hIGFBP)-4 protease in human osteoblasts using protease-resistant IGFBP-4 analogs. Journal of Bone and Mineral Research 14 2079-2088.

Qin X, Byun D, Lau KW, Baylink DJ \& Mohan S 2000 Evidence that the interaction between insulin-like growth factor (IGF)-II and IGF binding protein (IGFBP)-4 is essential for the action of the IGF-II-dependent IGFBP-4 protease. Archives of Biochemistry and Biophysics 379 209-216.

Qin X, Sexton C, Byun D, Strong DD, Baylink DJ \& Mohan S 2002 Differential regulation of pregnancy associated plasma protein (PAPP)-A during pregnancy in human and mouse. Growth Hormone and IGF Research 12 359-366.

Rajaram S, Baylink DJ \& Mohan S 1997 Insulin-like growth factorbinding proteins in serum and other biological fluids: regulation and functions. Endocrine Reviews 18 801-831.

Rechler MM 1993 Insulin-like growth factor binding proteins. Vitamins and Hormones 47 1-114.

Richardson RL, Hausman GJ \& Wright JT 1998 Growth factor regulation of insulin-like growth factor (IGF) binding proteins (IGFBP) and preadipocyte differentiation in porcine stromalvascular cell cultures. Growth, Development, and Aging 62 3-12.

Rivera GM \& Fortune JE 2003 Selection of the dominant follicle and insulin-like growth factor (IGF)-binding proteins: evidence that 
pregnancy-associated plasma protein A contributes to proteolysis of IGF-binding protein 5 in bovine follicular fluid. Endocrinology 144 437-446.

Rooman RP, De Beeck LO, Martin M, Van Doorn J, Mohan S \& Du Caju MV 2002 IGF-I, IGF-II, 'free' IGF-I and IGF-binding proteins-2 to -6 during high-dose oestrogen treatment in constitutionally tall girls. European Journal of Endocrinology 146 823-829.

Rosato R, Lindenbergh-Kortleve D, Neck J, Drop S \& Jahn G 2002 Effect of chronic thyroxine treatment on IGF-I, IGF-II and IGFbinding protein expression in mammary gland and liver during pregnancy and early lactation in rats. European Journal of Endocrinology 146 729-739.

Russo VC, Rekaris G, Baker NL, Bach LA \& Werther GA 1999 Basic fibroblast growth factor induces proteolysis of secreted and cell membrane-associated insulin-like growth factor binding protein-2 in human neuroblastoma cells. Endocrinology 140 3082-3090.

San Roman GA \& Magoffin DA 1993 Insulin-like growth factorbinding proteins in healthy and atretic follicles during natural menstrual cycles. Journal of Clinical Endocrinology and Metabolism 76 625-632.

Scharf JG, Schmidt-Sandte W, Pahernik SA, Ramadori G, Braulke T \& Hartmann H 1998 Characterization of the insulin-like growth factor axis in a human hepatoma cell line (PLC). Carcinogenesis 19 2121-2128.

Schiltz PM, Mohan S \& Baylink DJ 1993 Insulin-like growth factor binding protein-4 inhibits both basal and IGF-mediated chick pelvic cartilage growth in vitro. Journal of Bone and Mineral Research 8 391-396.

Schneider MR, Wolf E, Hoeflich A \& Lahm H 2002 IGF-binding protein-5: flexible player in the IGF system and effector on its own. Journal of Endocrinology 172 423-440.

Schuller AG, van Neck JW, Lindenbergh-Kortleve DJ, Groffen C, de Jong I, Zwarthoff EC \& Drop SL 1993 Gene expression of the IGF binding proteins during post-implantation embryogenesis of the mouse; comparison with the expression of IGF-I and -II and their receptors in rodent and human. Advances in Experimental Medicine and Biology 343 267-277.

Shimasaki S, Uchiyama F, Shimonaka M \& Ling N 1990 Molecular cloning of the cDNAs encoding a novel insulin-like growth factorbinding protein from rat and human. Molecular Endocrinology 4 1451-1458.

Shoubridge CA, Steeb CB \& Read LC 2001 IGFBP mRNA expression in small intestine of rat during postnatal development. American Journal of Physiology 281 G1378-G1384.

Singh P, Dai B, Dhruva B \& Widen SG 1994 Episomal expression of sense and antisense insulin-like growth factor (IGF)-binding protein-4 complementary DNA alters the mitogenic response of a human colon cancer cell line (HT-29) by mechanisms that are independent of and dependent upon IGF-I. Cancer Research $\mathbf{5 4}$ 6563-6570.

Smith EP, Kamyar A, Niu W, Wang J, Cercek B, Chernausek SD \& Fagin JA 2001 IGF-binding protein-4 expression and IGF-binding protein-4 protease activity are regulated coordinately in smooth muscle during postnatal development and after vascular injury. Endocrinology $1424420-4427$.

Soe R, Overgaard MT, Thomsen AR, Laursen LS, Olsen IM, Sottrup-Jensen L, Haaning J, Giudice LC, Conover CA \& Oxvig C 2002 Expression of recombinant murine pregnancy-associated plasma protein-A (PAPP-A) and a novel variant (PAPP-Ai) with differential proteolytic activity. European Journal of Biochemistry 269 2247-2256.

Soto L, Martin AI, Millan S, Vara E \& Lopez-Calderon A 1998 Effects of endotoxin lipopolysaccharide administration on the somatotropic axis. Journal of Endocrinology 159 239-246.

Spencer EM \& Chan K 1995 A 3-dimensional model for the insulinlike growth factor binding proteins (IGFBPs); supporting evidence using the structural determinants of the IGF binding site on IGFBP-3. Progress in Growth Factor Research 6 209-214.

Srinivasan N, Edwall D, Linkhart TA, Baylink DJ \& Mohan S 1996 Insulin-like growth factor-binding protein-6 produced by human PC-3 prostate cancer cells: isolation, characterization and its biological action. Journal of Endocrinology 149 297-303.

Standker L, Braulke T, Mark S, Mostafavi H, Meyer M, Honing S, Gimenez-Gallego G \& Forssmann WG 2000 Partial IGF affinity of circulating $\mathrm{N}$ - and $\mathrm{C}$-terminal fragments of human insulin-like growth factor binding protein-4 (IGFBP-4) and the disulfide bonding pattern of the C-terminal IGFBP-4 domain. Biochemistry 39 5082-5088.

Stewart CE \& Rotwein P 1996 Growth, differentiation, and survival: multiple physiological functions for insulin-like growth factors. Physiological Reviews 76 1005-1026.

Sun IY, Overgaard MT, Oxvig C \& Giudice LC 2002 Pregnancyassociated plasma protein A proteolytic activity is associated with the human placental trophoblast cell membrane. Journal of Clinical Endocrinology and Metabolism 87 5235-5240.

Thomas LN, Wright AS, Lazier CB, Cohen P \& Rittmaster RS 2000 Prostatic involution in men taking finasteride is associated with elevated levels of insulin-like growth factor-binding proteins (IGFBPs)-2, -4, and -5. Prostate 42 203-210.

Thomas T, Gori F, Spelsberg TC, Khosla S, Riggs BL \& Conover CA 1999 Response of bipotential human marrow stromal cells to insulin-like growth factors: effect on binding protein production, proliferation, and commitment to osteoblasts and adipocytes. Endocrinology 140 5036-5044.

Tonin P, Ehrenborg E, Lenoir G, Feunteun J, Lynch H, Morgan K, Zazzi H, Vivier A, Pollak M, Huynh H et al. 1993 The human insulin-like growth factor-binding protein 4 gene maps to chromosome region $17 \mathrm{q} 12-\mathrm{q} 21 \cdot 1$ and is close to the gene for hereditary breast-ovarian cancer. Genomics 18 414-417.

Ui M, Shimonaka M, Shimasaki S \& Ling N 1989 An insulin-like growth factor-binding protein in ovarian follicular fluid blocks follicle-stimulating hormone-stimulated steroid production by ovarian granulosa cells. Endocrinology 125 912-916.

Ulinski T, Mohan S, Kiepe D, Blum WF, Wingen AM, Mehls O \& Tonshoff B 2000 Serum insulin-like growth factor binding protein (IGFBP)-4 and IGFBP-5 in children with chronic renal failure: relationship to growth and glomerular filtration rate. The European Study Group for Nutritional Treatment of Chronic Renal Failure in Childhood. German Study Group for Growth Hormone Treatment in Chronic Renal Failure. Pediatric Nephrology 14 589-597.

Van Doorn J, Cornelissen AJ \& Buul-Offers SC 2001 Plasma levels of insulin-like growth factor binding protein-4 (IGFBP-4) under normal and pathological conditions. Clinical Endocrinology 54 655-664.

van Kleffens M, Groffen CA, Dits NF, Lindenbergh-Kortleve DJ, Schuller AG, Bradshaw SL, Pintar JE, Zwarthoff EC, Drop SL \& van Neck JW 1999 Generation of antisera to mouse insulin-like growth factor binding proteins (IGFBP)-1 to -6 : comparison of IGFBP protein and messenger ribonucleic acid localization in the mouse embryo. Endocrinology 140 5944-5952.

van Neck JW, Dits NF, Cingel V, Hoppenbrouwers IA, Drop SL \& Flyvbjerg A 2000 Dose-response effects of a new growth hormone receptor antagonist (B2036-PEG) on circulating, hepatic and renal expression of the growth hormone/insulin-like growth factor system in adult mice. Journal of Endocrinology 167 295-303.

Voci A, Demori, Bottazzi C \& Fugassa E 2001 Regulation of renal growth and IGFBP-4 expression by triiodothyronine during rat development. Hormone and Metabolism Research 33 256-262.

Wagner KJ, Patek CE, Miles C, Christie S, Brookes AJ \& Hooper ML 2001 Truncation of WT1 results in downregulation of cyclin G1 and IGFBP-4 expression. Biochemical and Biophysical Research Communications 287 977-982. 
Wang J, Niu W, Nikiforov Y, Naito S, Chernausek S, Witte D, LeRoith D, Strauch A \& Fagin JA 1997 Targeted overexpression of IGF-I evokes distinct patterns of organ remodeling in smooth muscle cell tissue beds of transgenic mice. Journal of Clinical Investigation 100 1425-1439.

Wang J, Niu W, Witte DP, Chernausek SD, Nikiforov YE, Clemens TL, Sharifi B, Strauch AR \& Fagin JA 1998 Overexpression of insulin-like growth factor-binding protein-4 (IGFBP-4) in smooth muscle cells of transgenic mice through a smooth muscle alpha-actin-IGFBP-4 fusion gene induces smooth muscle hypoplasia. Endocrinology 139 2605-2614.

Wang JF, Hampton B, Mehlman T, Burgess WH \& Rechler MM 1988 Isolation of a biologically active fragment from the carboxy terminus of the fetal rat binding protein for insulin-like growth factors. Biochemical and Biophysical Research Communications 157 718-726.

Westergaard JG, Chemnitz J, Teisner B, Poulsen HK, Ipsen L, Beck B \& Grudzinskas JG 1983 Pregnancy-associated plasma protein A: a possible marker in the classification and prenatal diagnosis of Cornelia de Lange syndrome. Prenatal Diagnosis 3 225-232.

Wetterau LA, Moore MG, Lee KW, Shim ML \& Cohen P 1999 Novel aspects of the insulin-like growth factor binding proteins. Molecular Genetics and Metabolism 68 161-181.

Wright RJ, Holly JM, Galea R, Brincat M \& Mason HD 2002 Insulin-like growth factor (IGF)-independent effects of IGF binding protein-4 on human granulosa cell steroidogenesis. Biology of Reproduction 67 776-781.

Yeh LC, Adamo ML, Kitten AM, Olson MS \& Lee JC 1996 Osteogenic protein-1-mediated insulin-like growth factor gene expression in primary cultures of rat osteoblastic cells. Endocrinology 137 1921-1931.

Yi HK, Hwang PH, Yang DH, Kang CW \& Lee DY 2001 Expression of the insulin-like growth factors (IGFs) and the IGF-binding proteins (IGFBPs) in human gastric cancer cells. European Journal of Cancer 37 2257-2263.

Zazzi H, Nikoshkov A, Hall K \& Luthman H 1998 Structure and transcription regulation of the human insulin-like growth factor binding protein 4 gene (IGFBP4). Genomics 49 401-410.

Zhang M, Smith EP, Kuroda H, Banach W, Chernausek SD \& Fagin JA 2002 Targeted expression of a protease-resistant IGFBP-4 mutant in smooth muscle of transgenic mice results in IGFBP-4 stabilization and smooth muscle hypotrophy. Journal of Biological Chemistry 277 21285-21290.

Zhou J \& Bondy C 1993 Anatomy of the human ovarian insulin-like growth factor system. Biology of Reproduction 48 467-482.

Received in final form 13 March 2003

Accepted 28 April 2003

Made available online as an Accepted Preprint

6 May 2003 